\title{
A proposed Albian To Lower Cenomanian nannofossil biozonation for England and the North Sea Basin
}

\author{
JASON JEREMIAH \\ Shell UK Exploration and Production, Shell-Mex House, Strand, London WC2R 0DX, UK.
}

\begin{abstract}
Analysis of abundant, diverse and well-preserved Albian nannofloral assemblages from onshore English sections has enabled a high-resolution nannofloral zonation to be developed with the construction of sixteen zones. The results are correlated with the ammonite zonation.

Five new species, Acaenolithus viriosus sp. nov., Staurolithites rotatus sp. nov., Staurolithites canthus sp. nov., Bownia glabra sp. nov. and Calculites percernis sp. nov. are described. J. Micropalaeontol. 15(2): 97-129, October 1996
\end{abstract}

\section{INTRODUCTION}

Extensive sampling of Albian, ammonite-dated field localities from England (Fig. 1) together with additional localities in Germany, France and the southern North Sea Shell/Esso well, 49/25a-9, has provided an opportunity for a refined Albian nannofossil biozonation scheme to be developed.

Prior to 1987, calcareous nannofossil zonations of the Albian generally had low resolution, e.g. Thierstein (1976), Sissingh (1977) and Perch-Nielsen (1979). Many of the marker species used in these zonations (see Fig. 18) are based on localities in Tethyan areas. These species are often rare, entirely absent or have different age ranges in the Boreal Realm.

Jakubowski (1987) highlighted the immense potential of using calcareous nannofossils to date the Lower Cretaceous using released well sections mainly from the Moray Firth Basin. He erected six zones for the Albian using a combination of last appearance datums (LAD), first appearance datums (FAD) and semi-quantitative events. However, he did not have the benefit of macrofossil-dated material and hence his correlations with the ammonite zonation were speculative.

This study attempts to establish a scheme useful both for academic workers and for industrial purposes, in which LADs and acme datums are regularly used. A total of sixteen zones are defined for the Albian. This study establishes a link between macrofossil (MF) and nannofossil (NF) biostratigraphies, thus extending interdisciplinary correlations both geographically and biostratigraphically. The zonation was developed in conjunction with studies of North Sea wells and its applicability in this area has been proven, although detailed primary data (except for well 49/25a-9) cannot be documented here for commercial reasons.

\section{METHODS}

\section{Sample preparation}

For light microscope examination, the samples were prepared by placing a small amount of sediment directly onto a microscope slide. A pipette was used to place a drop of distilled water onto the sample and smeared out into a thin layer by using a clean picking brush (size 101). The smeared sample was dried on a hot plate and a coverslip was attached using a permanent mounting medium. The picking brush is placed in $10 \% \mathrm{HCl}$ to remove any remaining residue.

\section{Counting technique}

Samples were examined with a light microscope at a magnification of $1000 \times$. A transect of thirty fields of view is taken with all specimens counted. Some species, e.g. Watznaueria barnesae, are so profuse that only ten or, in some instances, five fields of view are counted. Its abundance is subsequently multiplied out to thirty fields of view.

The following relative abundance categories which are used extensively in industry are also utilized in the present study:

rare : less than 1 specimen per 30 fields of view.

occasional : 1-2 specimens per 30 fields of view.

common : $3-10$ specimens per 30 fields of view.

abundant : 11-29 specimens per 30 fields of view.

influx : individuals are a major component of assemblage - greater than 29 specimens per 30 fields of view.

\section{MATERIAL STUDIED}

The stratigraphic results presented here are based on data from several localities in England and northwest Europe together with knowledge gained from numerous exploration wells drilled throughout the North Sea. The localities studied are discussed briefly in the following sections. Nannofossils recovered in these sections are presented in range charts (Figs 2-16).

1. Folkestone area and Eastbourne

2. Cambridgeshire, Bedfordshire and Buckinghamshire

3. Yorkshire

4. Mt. Risou, southeast France

5. Vöhrum, Germany

6. Shell/Esso 49/25a-9

The locations of field samples studied from mainland UK 


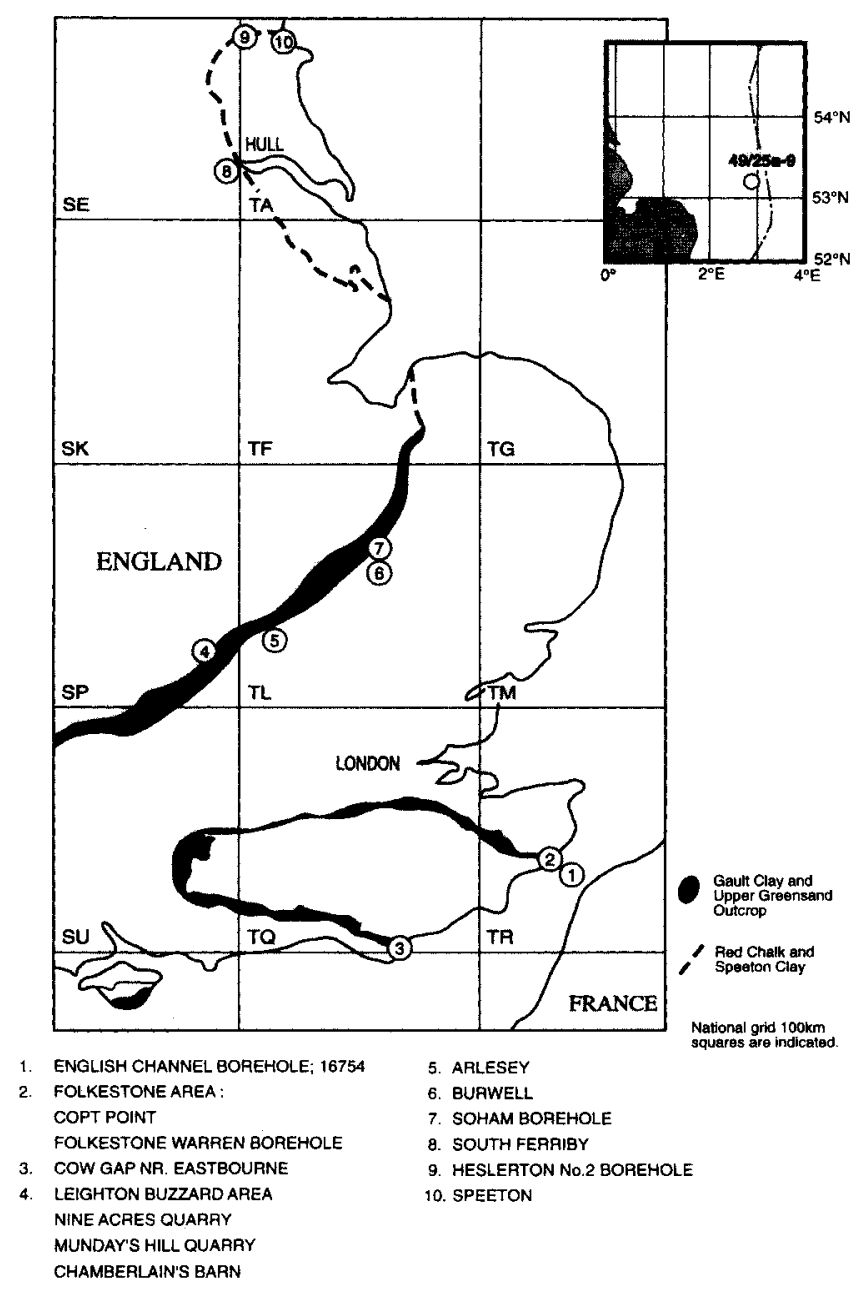

Fig. 1. Locations of the sections studied from mainland and offshore UK.

are indicated on Fig. 1. Precise locations are cited below relative to the UK national grid (e.g. TV 955 596). A chronostratigraphic synopsis of the studied localities is given in Fig. 17.

\section{FOLKESTONE AREA AND EASTBOURNE}

\section{(a) Copt Point [TR 2414 3645]}

The classic Gault Clay succession at Copt Point near Folkestone was used to establish a correlation between the ammonite-dated clays and the nannofloral assemblages (Fig. 2). The sediments are lithologically subdivided into Beds I-XIII, Price (1874), Jukes-Browne \& Hill (1900). The bulk of Bed XIII, however, together with Bed XII and the upper part of Bed XI were not exposed due to slumping. This part of the sequence was sampled from the Folkestone Warren borehole.

(b) Folkestone Warren borehole [TR 24473 77813]

The Folkestone Warren borehole (Fig. 3) can be viewed at BGS, Keyworth (Reg. No. TR23NW No. 10). The nannofloral assemblages indicate a marked hiatus at the Bed
X1/Bed X11 boundary. NF Zone NAL 12 rests directly upon NAL 9.

\section{(c) English Channel borehole 16754}

A more complete Albian/Cenomanian boundary succession, than that preserved at Folkestone, is documented from English Channel boreholes (Carter \& Hart, 1977; Amédro, 1994). Four samples were analysed (Fig. 4) from this borehole (Zone 6a of Carter \& Hart, 1977). Lithofacies data and foraminiferal assemblages suggest a Lower Cenomanian age for Zone 6a, although macrofossil information is sparse.

(d) Cow Gap near Eastbourne [TV 955 596]

This section (Fig. 5) was described by Price (1879). Additional macrofossil and lithological data were provided by A.S. Gale (pers. comm., 1994).

\section{CAMBRIDGESHIRE, BEDFORDSHIRE AND BUCKINGHAMSHIRE}

The Albian Gault Clay in East Anglia, Bedfordshire and Buckinghamshire consists of calcareous mudstones with rich nannofloras. The assemblages exhibit localized acmes of species that are rare elsewhere in England and in the central North Sea.

The Gault Clay is exposed in numerous quarries in the Leighton Buzzard area. The key outcrops studied are listed below.

(a) Chamberlain's Barn [SP 926 264]

This section (Fig. 9) was described by Lamplugh (1922) and Casey (1961). The most recent descriptions of the section are by Owen (1972) and Eyers (1992).

\section{(b) Munday's Hill [SP 939 282]}

Munday's Hill was described in detail by Owen (1972) and Eyers (1992). The nannofossil biostratigraphy of this section was documented by Crux (1991). A nannofloral chart is therefore not figured in this study although samples examined are documented in Appendix 2 together with NF zones and relevant discussion.

\section{(c) Nine Acres Quarry [SP 939 278]}

Nine Acres Quarry (Fig. 7) lies approximately $150 \mathrm{~m}$ southeast of the Munday's Hill section. A reduced sequence of ?spathi to intermedius MF Subzonal mudstones are exposed (Eyers, pers. comm., 1992).

\section{(d) Arlesey [TL 186 354]}

This section (Fig. 8) is described by Eyers (1992). Additional macrofossil data were supplied by H. G. Owen, pers. comm., 1994.

Chalk sedimentation was initiated earlier at Arlesey than at Folkestone. The $\mathrm{NC1}$ marker, Calculites anfractus has a FAD approximately $3 \mathrm{~m}$ above the base Chalk at Arlesey whilst at Folkestone the FAD of $C$. anfractus is $2 \mathrm{~m}$ (pers. obs.) above the top of Bed X111 within glauconitic mudstones.

Two sections were studied in Cambridgeshire - (e) and (f). 


\section{(e) Burwell [TL 577 687]}

The ammonite fauna and lithological subdivisions of the Burwell section (Fig. 10) are documented by Gallois \& Morter (1982). Additional macrofossil information was supplied by J. Eyers (pers. comm., 1993).

The top of the auritus MF Subzone in East Anglia is often missing or highly condensed (J. Eyers, pers. comm., 1993). There is evidence of this hiatus at Burwell where Eiffellithus monechiae appears $10 \mathrm{~cm}$ below a phosphatic horizon. In Bedfordshire, however, the upper part of the auritus MF Subzone is locally more complete. At Munday's Hill at least $4 \mathrm{~m}$ of the latest auritus MF Subzone is present (top not seen) and here Eiffellithus monechiae eventually becomes common.

At Burwell, sediments of rostratum MF Subzone age lie unconformably upon the upper part of the auritus $\mathrm{MF}$ Subzone. The very pale grey mudstones of Bed 17 are intensely bioturbated throughout. This bed is, in parts, poorly exposed due to slumping. No younger Albian sediments are preserved at Burwell.

The presence of NF Zone NAL 11 indicates that Bed 17 has no lithological equivalent at Folkestone due to an erosional phase which is expressed in phosphatic nodules at the base of the 'Greensand Seam', Bed XII.

(f) Soham borehole [TL 593 745]

The Soham borehole (Fig. 6) can be viewed at BGS, Keyworth (Reg. TL57SE No. 1). Macrofossil determinations are based on Eyers (1992).

\section{YORKSHIRE}

\section{(a) Speeton [TA 155 755]}

The upper part of the Speeton Clay at Speeton (Fig. 12) and the overlying Red Chalk are almost devoid of ammonites. Lamplugh (1924) divided the clays into five subdivisions lettered $\mathrm{A}$ to $\mathrm{E}$ in descending sequence using the more abundant and better preserved belemnites. The A Beds are of Albian age and were subdivided A1 to A5 by Wright (1935)

The dark clays representing Bed A5 contain the belemnite Neohibolites ewaldi and were originally correlated with the Aptian Sutterby Marl of Lincolnshire by Spath (1924). The upper part of these beds, however, contain a Lower Albian ostracod assemblage (Kaye, 1964). This age assignment is supported by the palynological flora which contains Kleithriasphaeridium simplicispinum and lacks any Aptian markers (R. Davey, pers. cornm., 1993).

The 'Greensand Streak', Bed A4, and the basal part of Bed A3 are non-calcareous and barren of calcareous nannofossils. Kaye (1964) postulated a Middle Albian age for these beds. The overlying sediments, however, yield Lower Albian nannofloral assemblages (NF Zone NAL 3) similar to those found in the mammillatum MF Zone at Chamberlain's Barn, Bedfordshire. Brown clays were also found yielding the Middle Albian markers, Ceratolithina cruxii and Crucicribrum anglicum (NF Zone NAL 4) associated with Hamites and Hoplites ammonites (A.S. Gale, pers. comm., 1996), but their exact level from within Bed A3 was not established. It should be noted that extensive slumping occurs at this level (P. Rawson, pers. comm., 1994). Due to slumping, Beds $A 2$ and $A 1$ were not sampled, although Euhoplites and Mortoniceras ammonites have previously been recovered from Bed A1 and indicate an Upper Albian age. The overlying Red Chalk $(16.1 \mathrm{~m})$ is also regarded as Upper Albian. Further south, at South Ferriby, in proximity to the Market Weighton High the Red Chalk ( = Hunstanton Formation) is only $2.5 \mathrm{~m}$ thick and, in part, forms a highly condensed lateral equivalent of the Red Chalk Formation at Speeton and the offshore southern UK Sector of the North Sea.

\section{(b) Heslerton No. 2 borehole [SE 9199 7589]}

This Heslerton No. 2 borehole can be viewed at BGS, Keyworth. Macrofossil data are limited from the interval studied in this borehole (P. Rawson, pers. comm., 1994). Nannofossil data (Fig. 11) suggests these sediments are equivalent to the top of Bed A5, Bed A4 and the base of Bed A3, as exposed at Speeton.

\section{(c) South Ferriby, Humberside [SE 911 204]}

The Carstone Formation at South Ferriby is considered to be of Lower Albian age based on the brachiopod fauna (Whitham, 1991). This formation, which consists of hard, iron- rich, pebbly sands, is non-calcareous and barren of nannofossils.

At Melton Bottoms [SE 970 270], just north of South Ferriby, the basal red marls of the Hunstanton Formation are considered to be of Middle Albian age (Whitham, 1991) based on a single whorl fragment of the ammonite Dimorphoplites cf. hilli Spath. The absence of Middle Albian NF zones at South Ferriby (Fig. 13) is possible evidence of a diachronous base to the Red Chalk particularly over the Market Weighton High. Sediments equivalent to the auritus MF Subzone are absent. This stratigraphic break is also present at the Heslerton No. 2 borehole (D. Rutledge, pers. comm., 1994) and possibly at Speeton (pers. obs.).

The upper part of the Hunstanton Formation at South Ferriby is equivalent to the majority of the Red Chalk at Speeton.

\section{MT RISOU, SOUTHEAST FRANCE (ROSANS:1:25 000, LAMBERT ZONE II, 1937: 853.2- 3239)}

The section at Mt. Risou (Fig. 15) exposes a thick succession of marls and minor limestones across the Albian/ Cenomanian boundary which have been accurately dated with ammonites (A.S. Gale, pers. comm., 1994).

This is the only location in the present study where common/abundant Broinsonia enormis have been found in Upper Albian dated sediments. A hiatus is present at this level in southern Britain.

The NF Zone NC1 nominate marker, Calculites anfractus is found at Mt. Risou. The FAD at this locality is stratigraphically higher than that seen further north in southern England, where $C$. anfractus is found associated with Bownia glabra and Gartnerago chiasta. It appears that C. anfractus, although not endemic to the Boreal Realm, as 


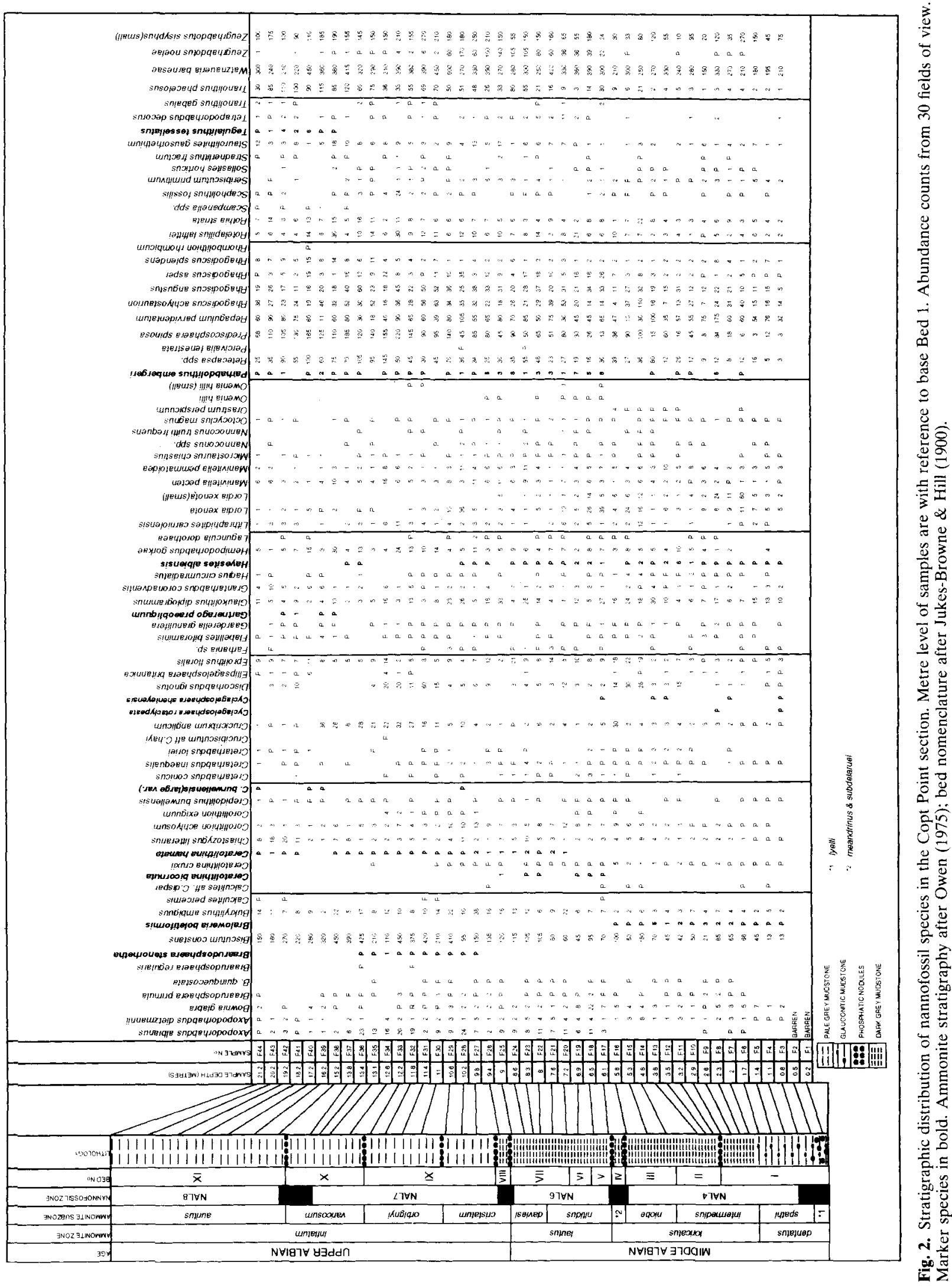



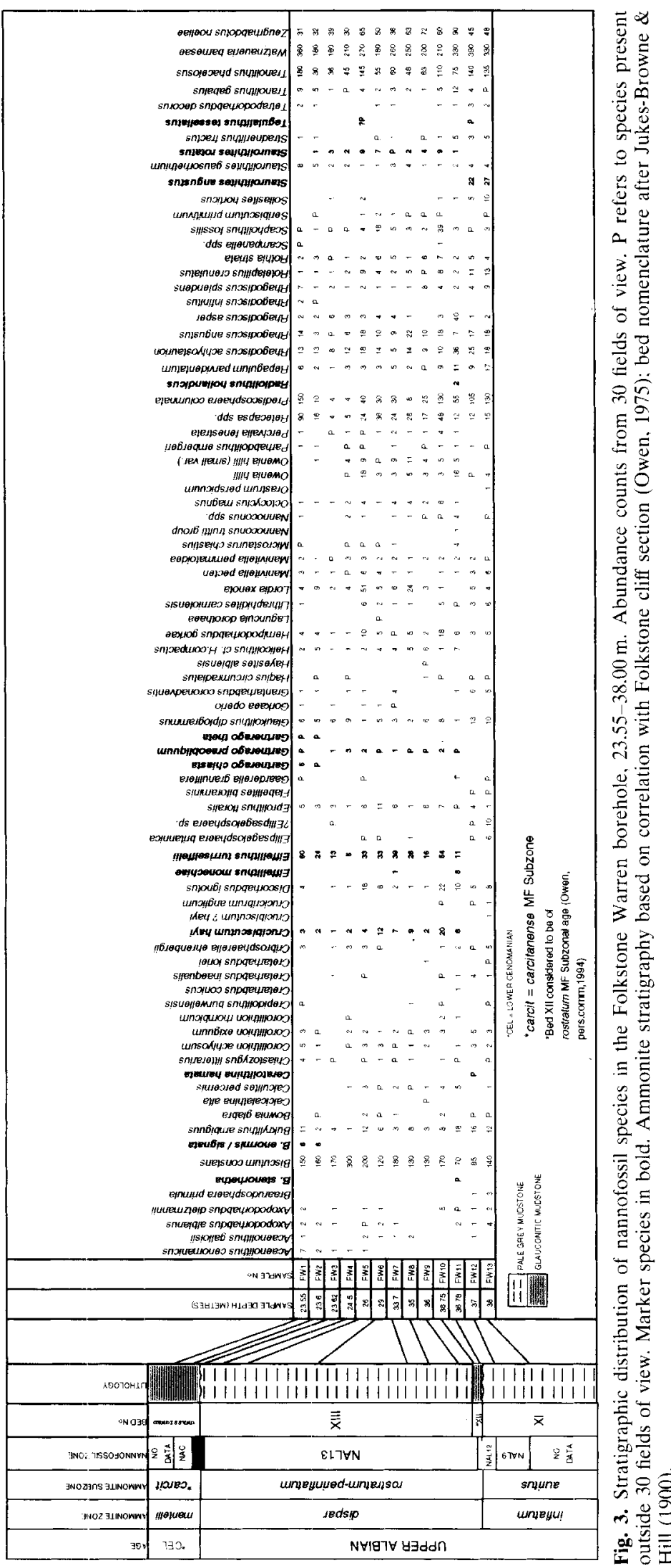

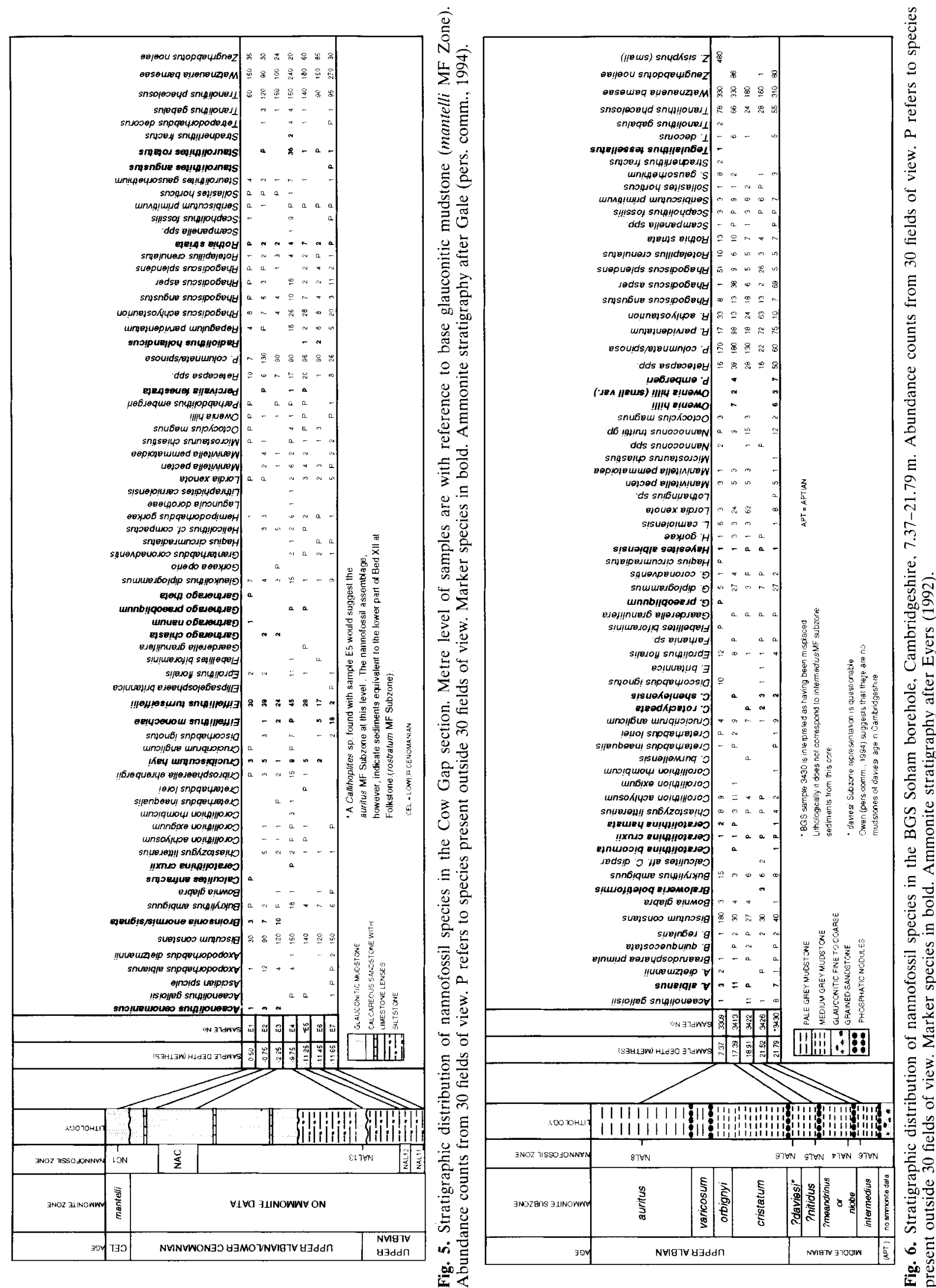
A proposed Albian to lower Cenomanian nannofossil biozonation

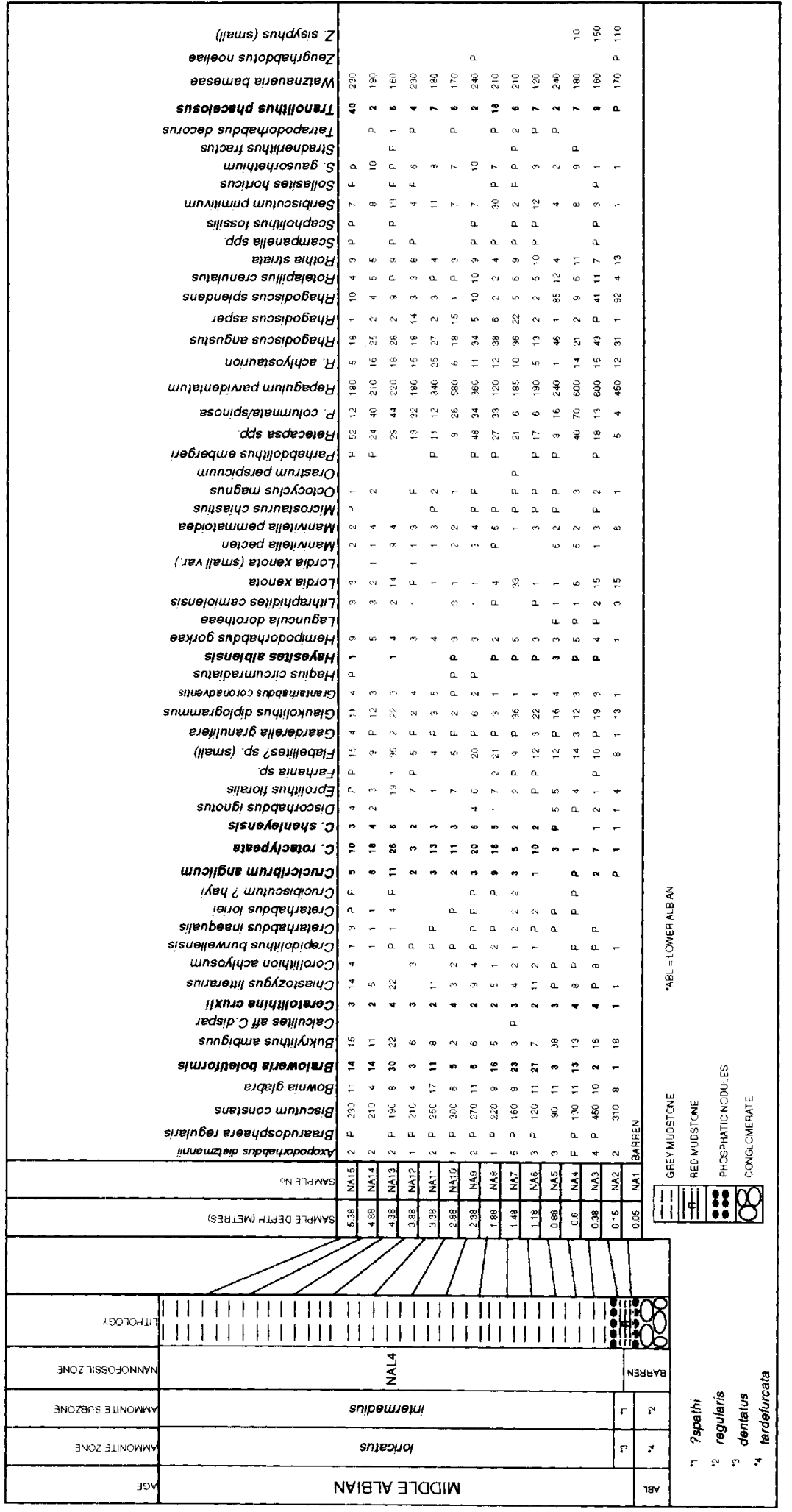




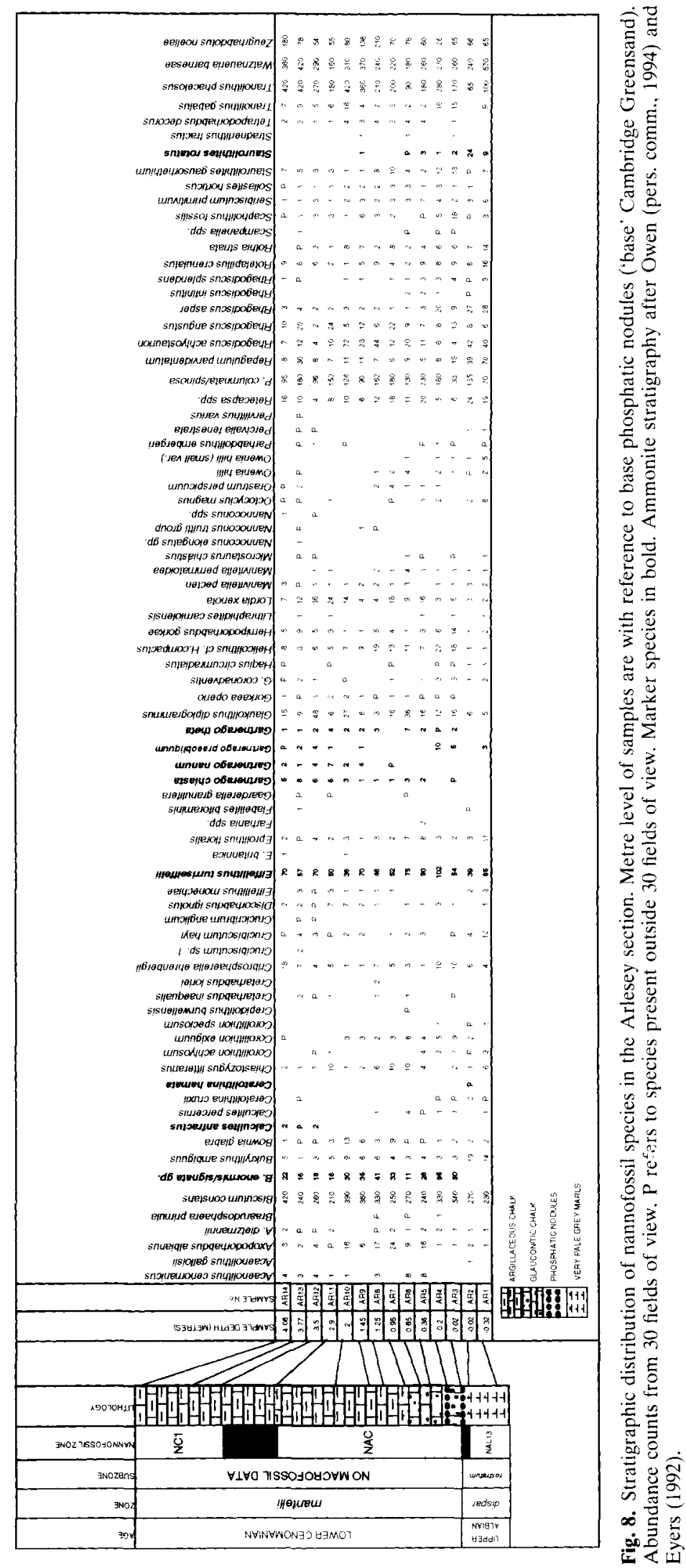




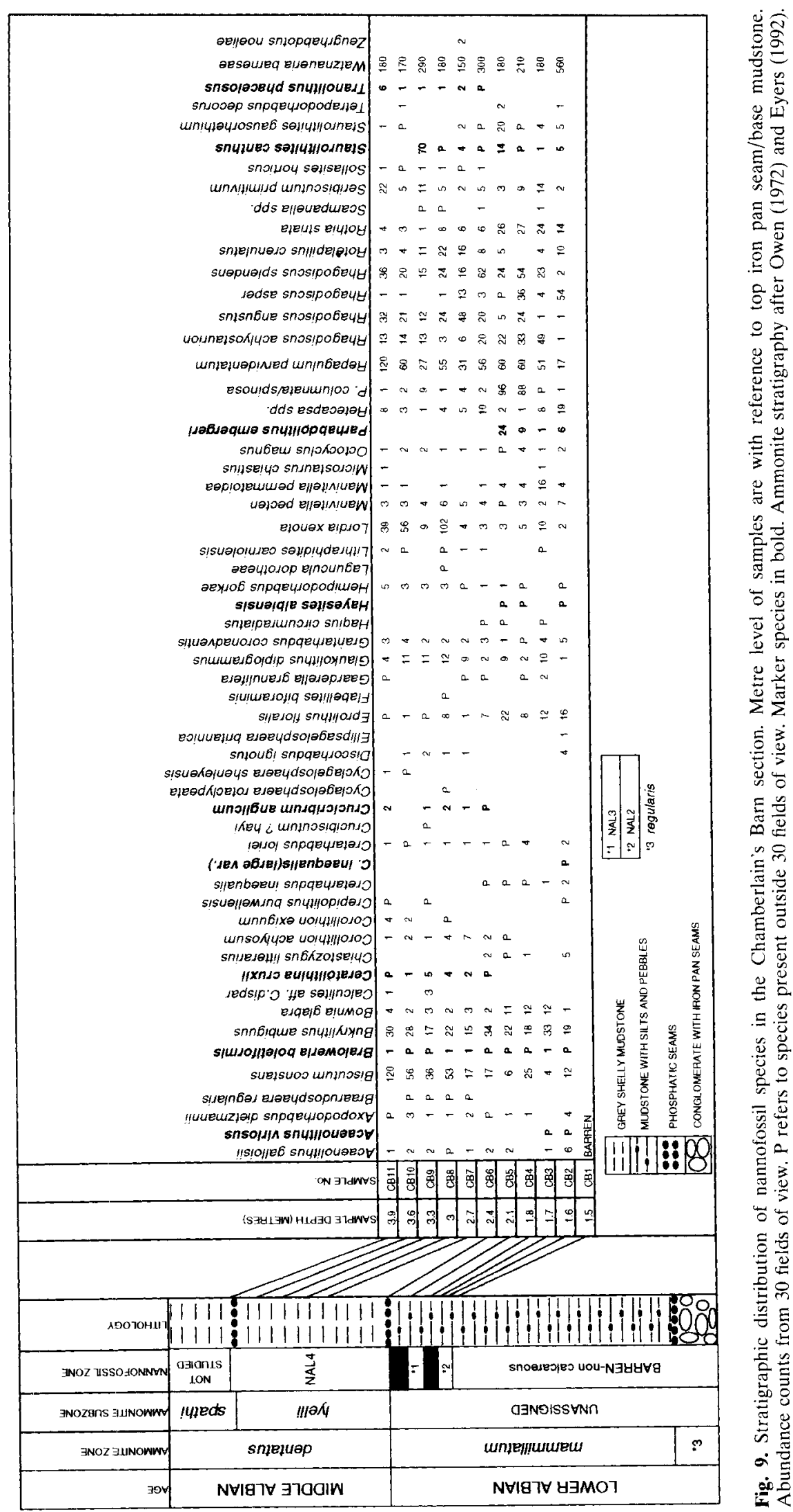




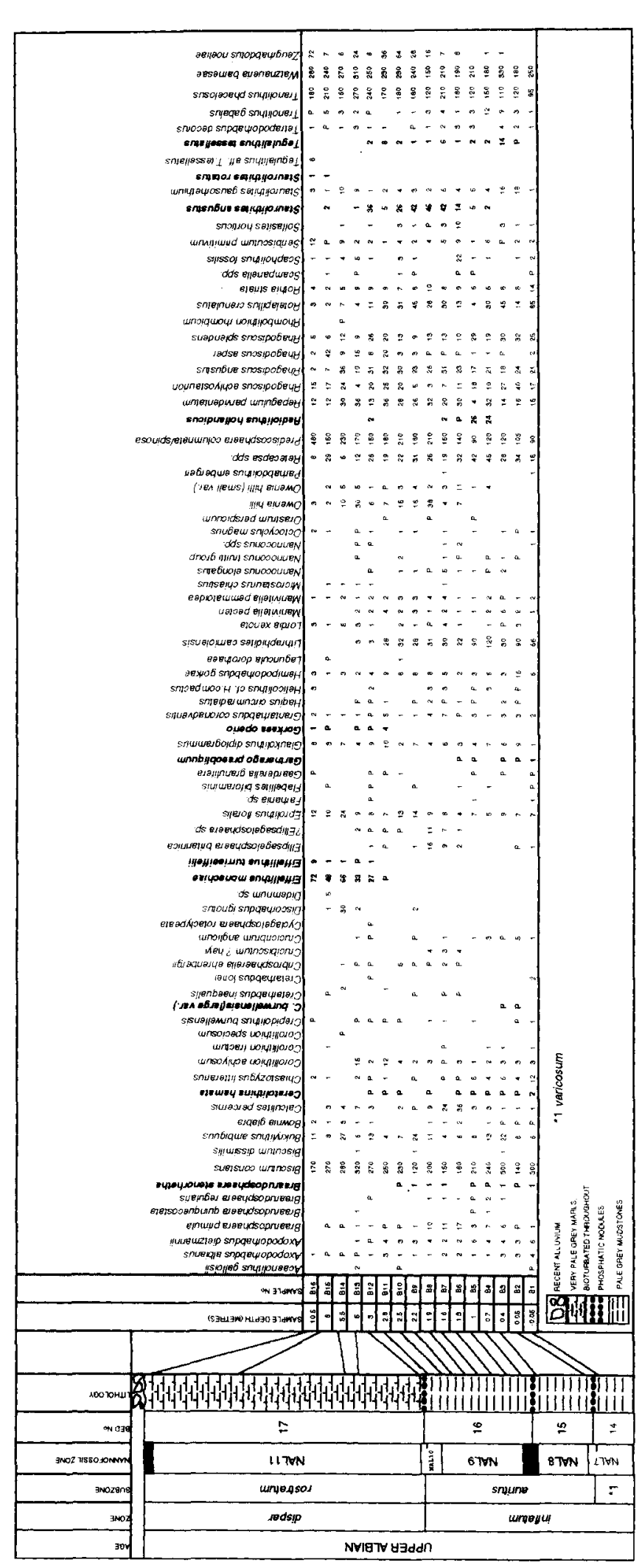

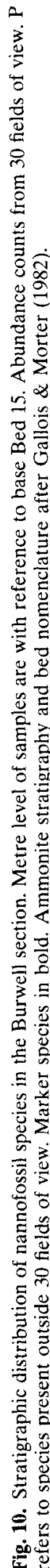


A proposed Albian to lower Cenomanian nannofossil biozonation

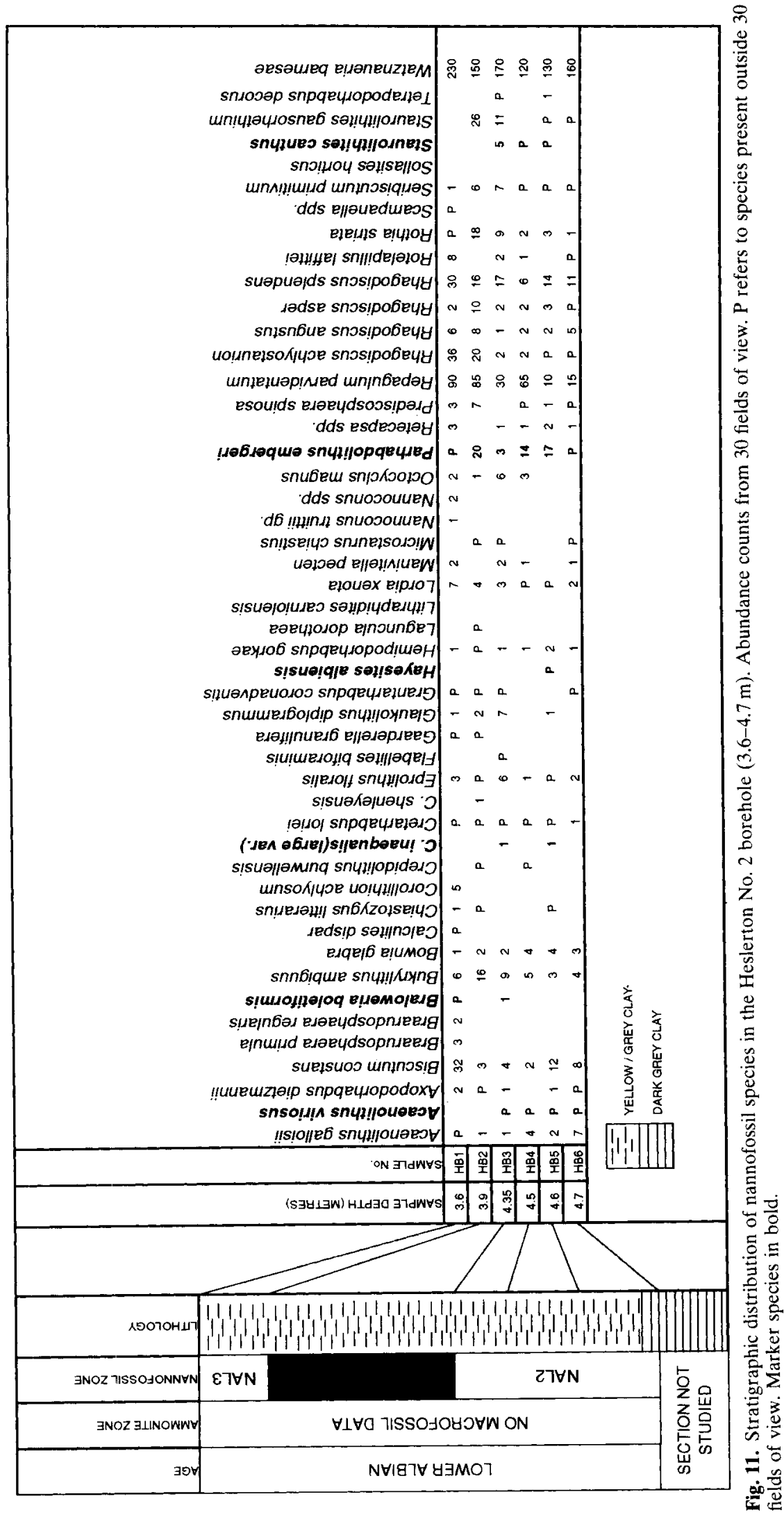




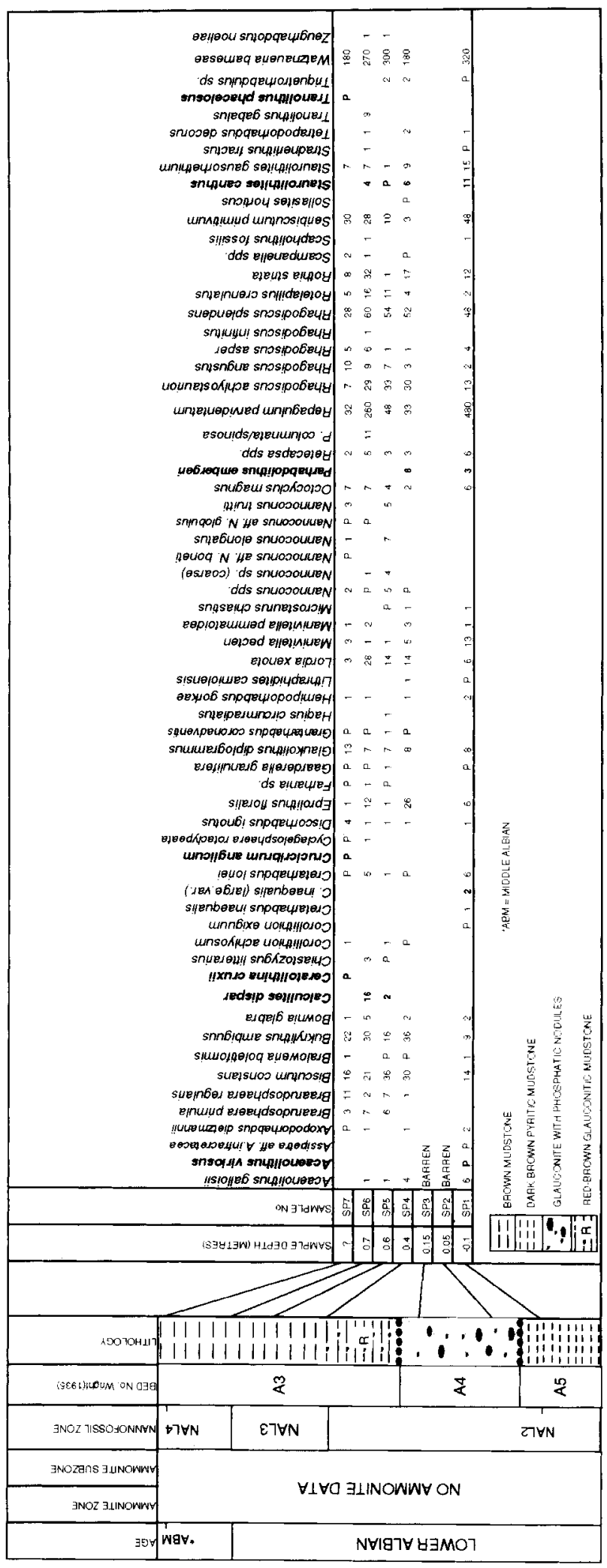


A proposed Albian to lower Cenomanian nannofossil biozonation

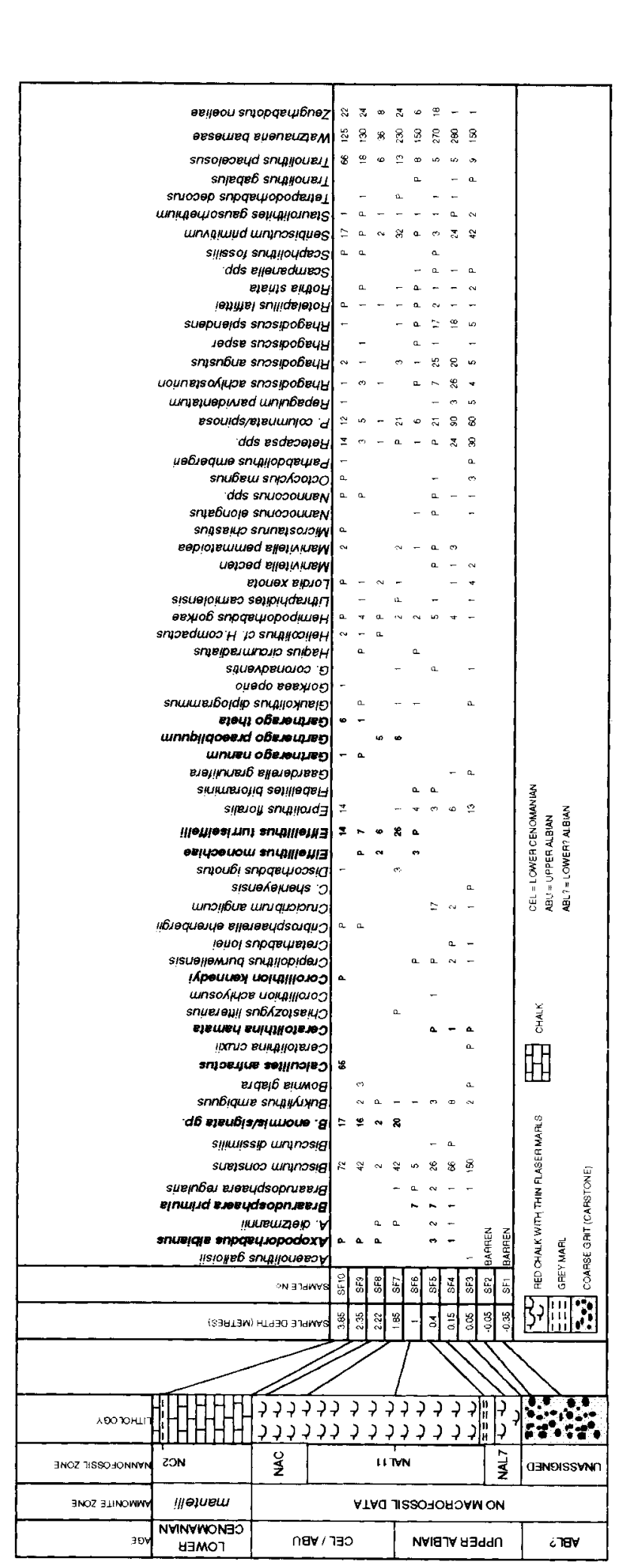

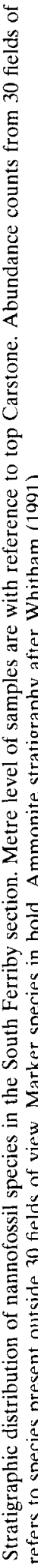


Jeremiah

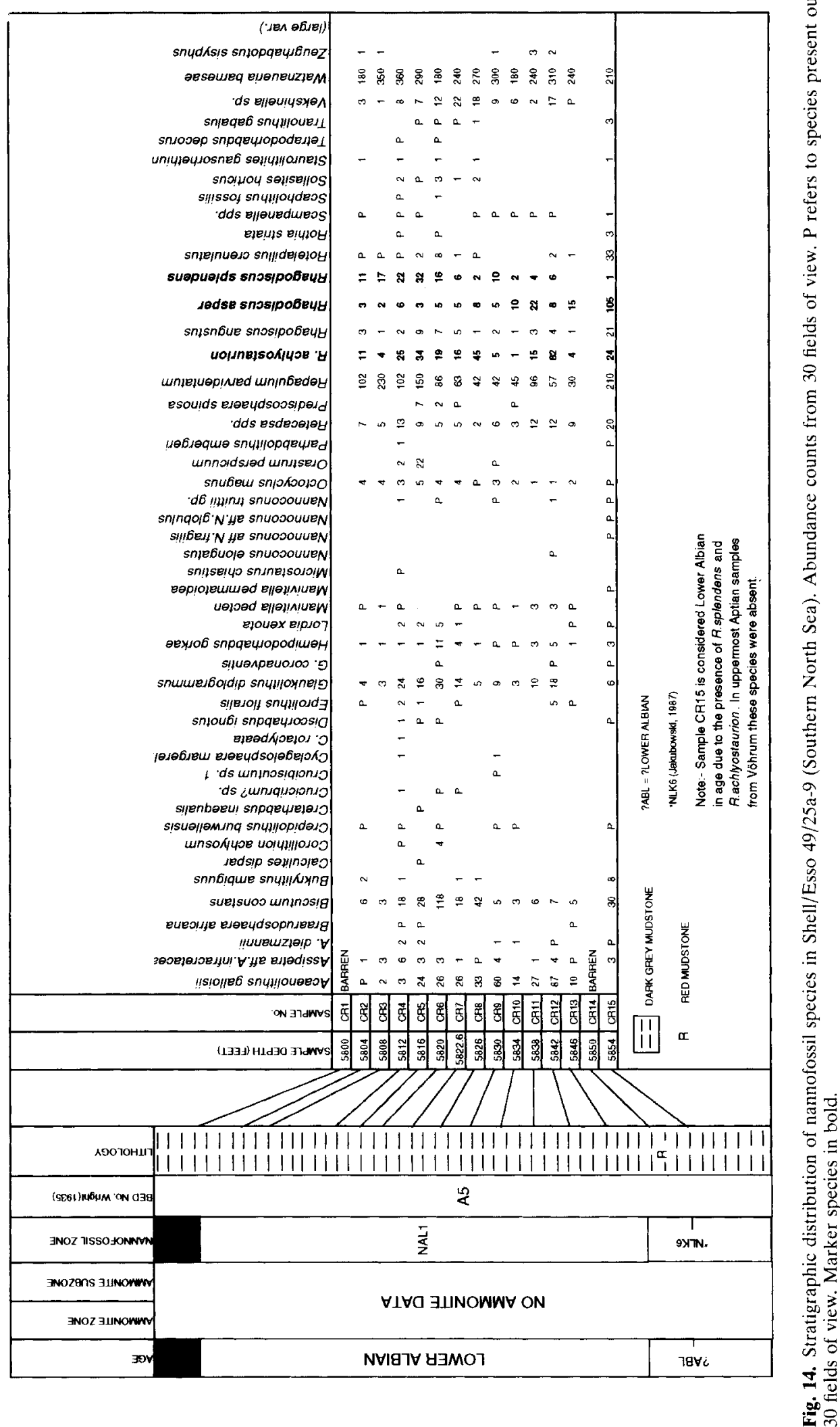


A proposed Albian to lower Cenomanian nannofossil biozonation

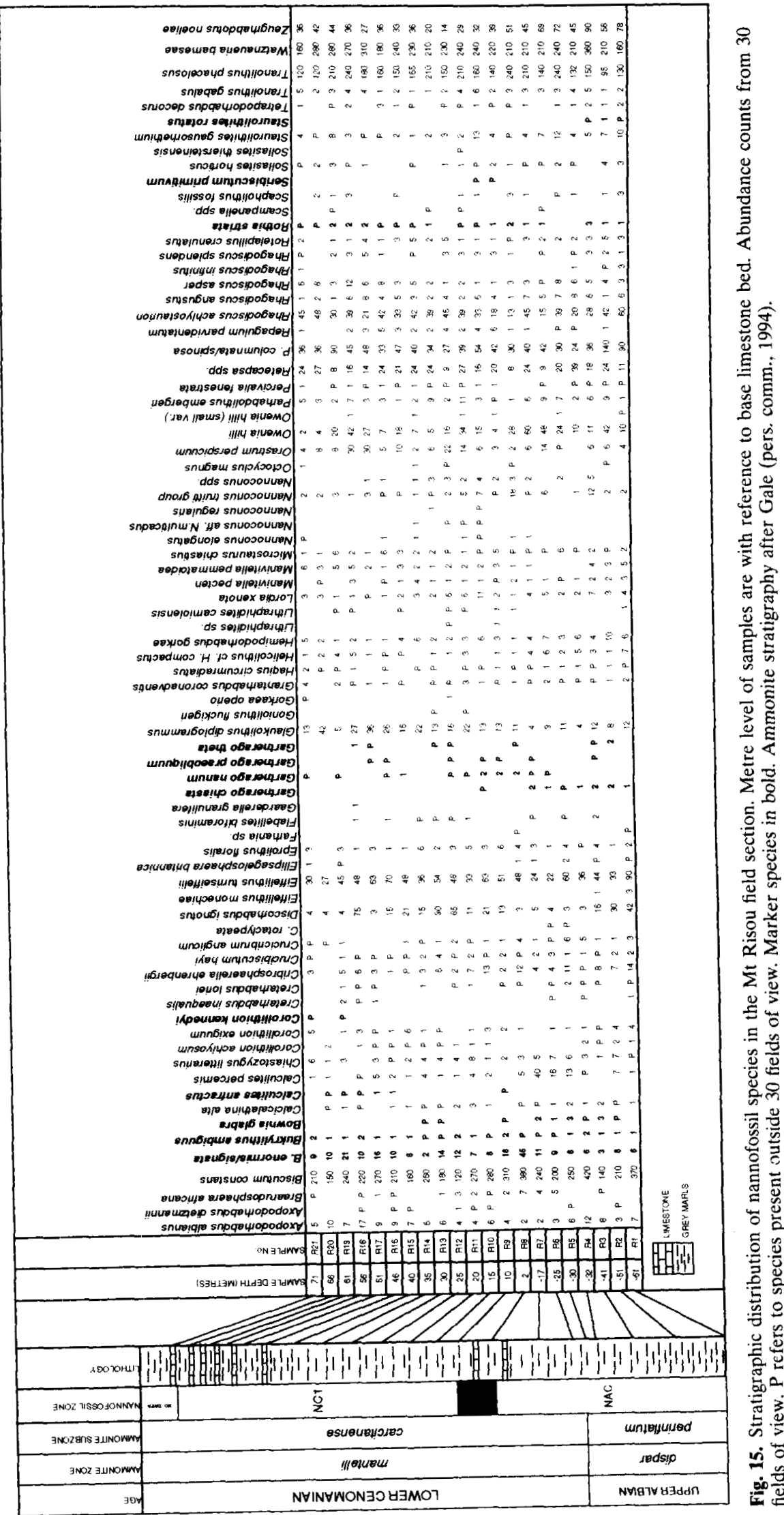


this study has proven, certainly preferred high latitudes. The isolated occurrence of $C$. anfractus within sample R9 may indicate an earlier cold water incursion from the north. This is supported by the presence of Seribiscutum primitivum, a form characteristic of Boreal Realm Albian nannofloral assemblages (Crux, 1991 and pers. obs.) but extremely rare at the Mt. Risou section.

\section{VÖHRUM, NORTHWEST GERMANY Vö TK 25 HÄMELERWALD No. 3626 (re: 3578800 , h: 5800000 )}

This locality (Fig. 16) exposes a succession of dark grey to black mudstones of Lowermost Albian to Uppermost Aptian age. A secondarily altered tuff is located at the Albian/Aptian boundary. The calcareous nannofossils of this section have been studied by Cepek (1982) and Mutterlöse (1989). The assemblages are of low abundance and diversity.

A detailed analysis of the sequence is given by Kemper \& Zimmerle (1978) and Kemper (1982).

\section{SHELL/ESSO SOUTHERN NORTH SEA WELL: 49/25a-9 (latitude $53^{\circ} 12^{\prime} 37.760^{\prime \prime} \mathrm{N}$, longitude $02^{\circ} 55^{\prime}$ $20.328 " E$ )}

This well (Fig. 14) is located approximately $20 \mathrm{~km}$ west of the UK/Netherlands median line in the UK southern North Sea.

\section{ZONATION}

The zonation outlined below was developed as a practical tool for subdividing the Albian to Lower Cenomanian of onshore sections, mainly from England and offshore material from throughout the North Sea Basin. Work was started with the aim of improving on the NF scheme of Jakubowski (1987) and constructing a scheme useful for both academic and industrial purposes. In this study, sixteen zones are defined for the Albian/Lower Cenomanian interval. They are correlated with the MF zones and compared with previous NF zonations in Fig. 18 . A composite range chart of biostratigraphically useful species is presented in Fig. 19.

\section{Bukrylithus ambiguus Interval Range NF Zone (NLK6, Jakubowski, 1987)}

Definition: Interval from LAD of Micrantholithus hoschulzii to LAD of abundant Rhagodiscus asper.

Age: Lower Albian/Upper Aptian.

Remarks: In this study no change in nannofloral assemblages is identified over the Aptian/Albian boundary.

Abundant $R$. asper are found sporadically throughout the

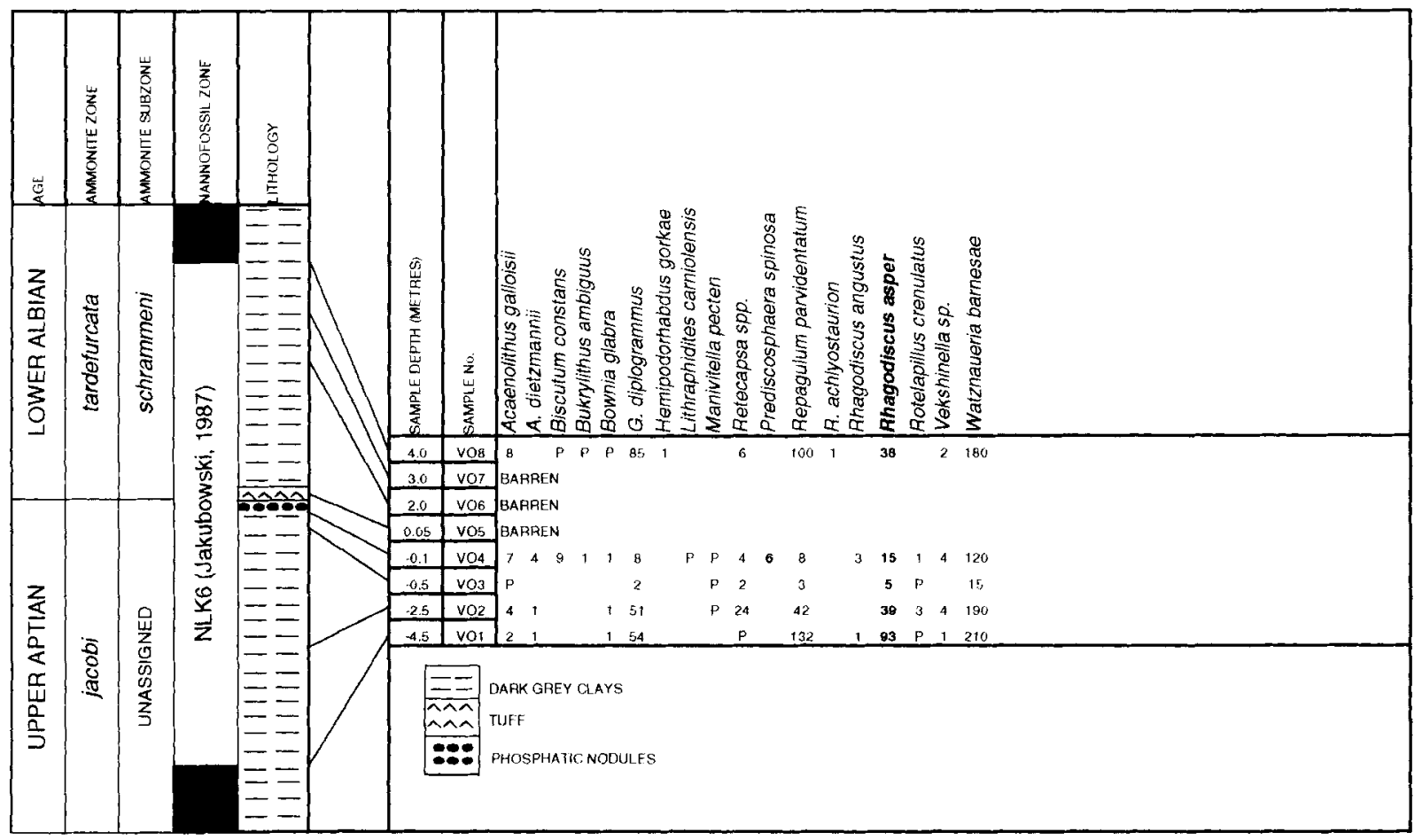

Fig. 16. Stratigraphic distribution of nannofossil species in the Vohrum section. Metre level of samples are with reference to base tuff. Abundance counts from 30 fields of view. P refers to species present outside 30 fields of view. Marker species in bold. Ammonite stratigraphy after Kemper \& Zimmerle (1978). 
A proposed Albian to lower Cenomanian nannofossil biozonation

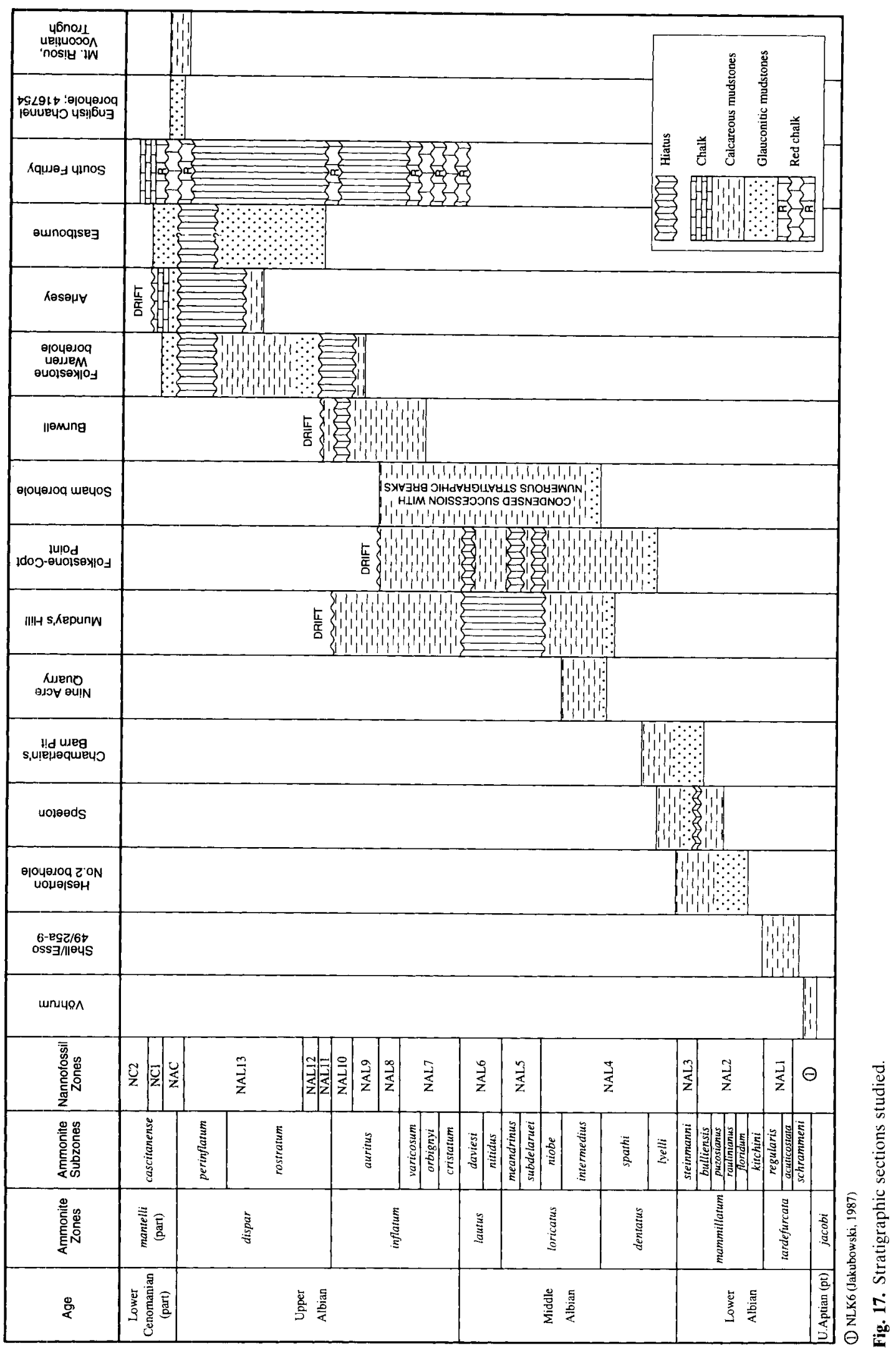




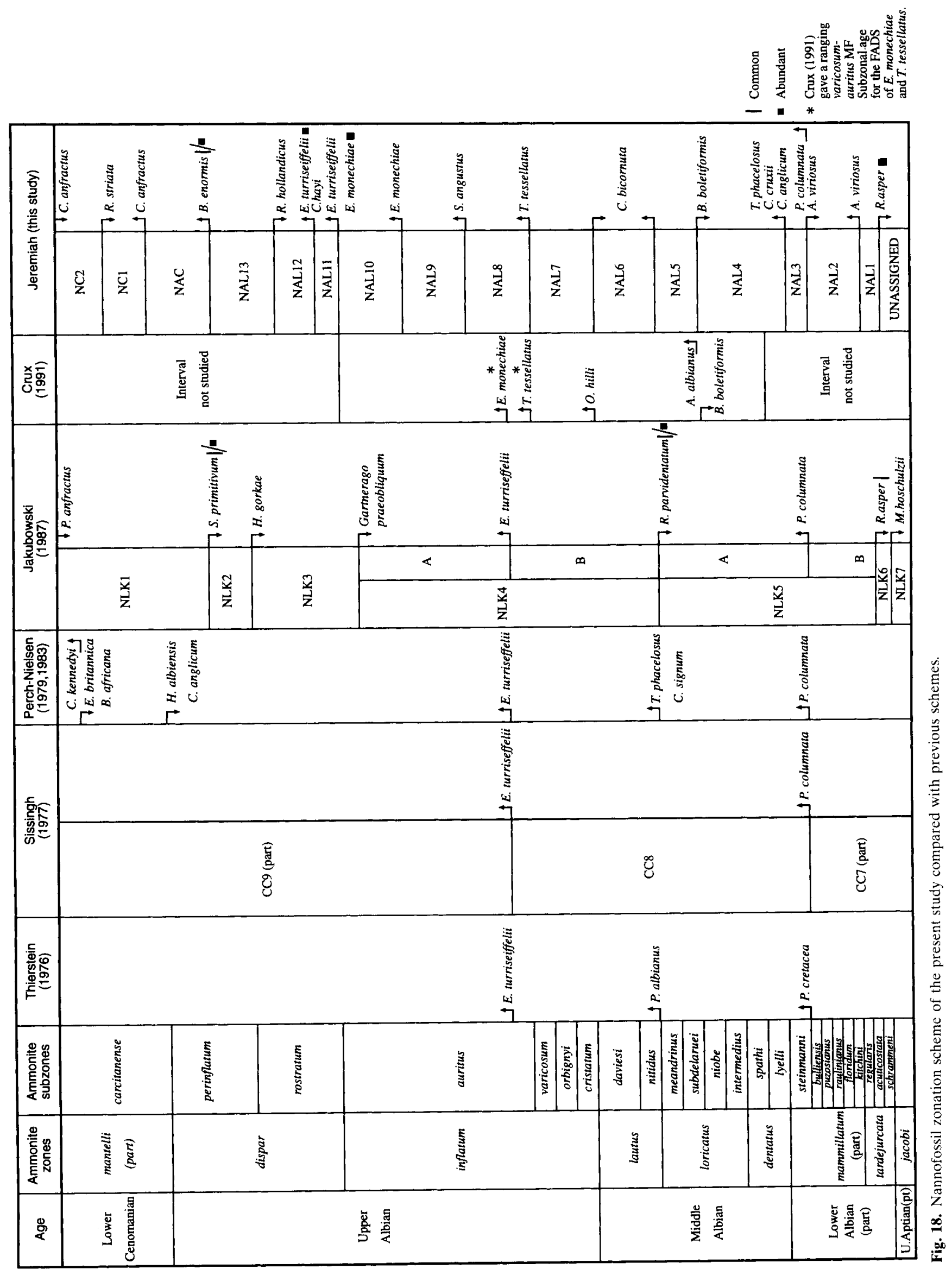


Middle/Upper Albian. It is, however, only in basal Albian and older sediments that $R$. asper is a major component of assemblages. At Vöhrum, $R$. asper makes up between $15 \%$ and $30 \%$ of the total nannoflora when Watznaueria barnesae is discounted. This event is probably equivalent to the Bukrylithus ambiguus Zone (NLK 6) of Jakubowski (1987) based on the LAD of common $R$. asper (common occurrence was defined as 3 to 15 specimens per 30 fields of view, pers comm., 1995).

Micrantholithus hoschulzii, the top Aptian marker of Jakubowski, 1987 ( Zone NLK 7) is not identified from jacobi MF dated sediments at Vöhrum or numerous cored wells studied in the Moray Firth area (pers. obs.) and appears to have an intra Upper Aptian (nutfieldiensis MF Zone) LAD in the North Sea Basin (pers. obs.). Mutterlöse (1991) suggests an even earlier LAD for $M$. hoschulzii within the drewi MF Zone of Germany.

\section{Repagulum parvidentatum Interval Range NF Zone (NAL 1)}

Definition: Interval from LAD of abundant Rhagodiscus asper to FAD of Acaenolithus viriosus.

Age: Lower Albian, ?tardefurcata MF Zone.

Remarks: NF Zone NAL 1 is rarely identified in the central and northern North Sea as a result of noncalcareous lithologies. In the southern North Sea, however, calcareous mudstones are locally developed equivalent to the lower part of the A5 Beds at Speeton.

\section{Acaenolithus viriosus Taxon Range NF Zone (NAL 2) \\ Definition: Total range of Acaenolithus viriosus.}

Age: Lower Albian, mammillatum MF Zone.

Remarks: The FAD of $A$. viriosus could not be correlated with the MF Zonation due to limited onshore material studied over this interval. This event, however, is biostratigraphically restricted to an intra Lower Albian age based on the absence of $A$. viriosus from schrammeni MF dated mudstones at Vöhrum and uppermost mammillatum MF dated mudstones at Chamberlain's Barn.

\section{Crucicribrum anglicum Partial Range Zone (NAL 3)}

Definition: Interval from LAD of Acaenolithus viriosus to FAD of Crucicribrum anglicum (and Ceratolithina cruxii).

Age: Lower Albian, top mammillatum MF Zone (steinmanni MF Subzone).

Remarks: The FAD of Prediscosphaera columnata was used by Thierstein (1976), Sissingh (1977), Perch-Nielsen (1979, 1983) and Jakubowski (1987) as a zonal boundary. In the present study $P$. columnata was, however, found to be sporadic towards the base of its range in the uppermost Lower Albian at Speeton and Chamberlain's Barn. In the Tethyan Realm, however, the FAD of $P$. columnata, in the absence of other markers, is a useful approximation to the base of the Middle Albian. Under the light raicroscope no differentiation could be made between $P$. spinosa and $P$. cf. stoveri.
Braloweria boletiformis Partial Range NF Zone (NAL 4) Definition: Interval from FAD of Crucicribrum anglicum (and Ceratolithina cruxii) to LAD of Braloweria boletiformis.

Age: Middle Albian, base of lyelli MF Subzone to top of niobe MF Subzone.

Remarks: Axopodorhabdus albianus has its FAD at the base of the intermedius MF Subzone both at Folkestone (Bed II) and at Mundays Hill (pers. obs.) but the occurrences are extremely rare and sporadic. These records, however, support the identification of $A$. albianus by Amédro et al. (1981) from coeval sediments at Boulonnais, France.

The FAD of A. albianus which was used by Cepek \& Hay (1969), Thierstein (1976) and Roth (1978) as a zonal marker is not taken as a reliable datum in this study due to its extreme rarity at the base of its range. Records of $A$. albianus below the Middle Albian (Perch-Nielsen, 1985) are probably due to contamination or misidentification. The presence of $A$. albianus and Ceratolithina hamata in the niobe MF Subzone (Crux, 1991) is possibly due to mis-sampling over the niobe/cristatum stratigraphic break. Hayesites albiensis is inconsistently present and usually rare in the sections studied. The rare and intermittent occurrence limits any biostratigraphical usefulness. It however, appears to be more consistently present in localities from Kent than further north in Cambridgeshire and Bedfordshire. Hayesites albiensis was not identified from Yorkshire field sections or the North Sea Basin.

Braloweria boletiformis, however, is far more widespread than previously recognized. It is consistently present in the condensed Middle Albian successions of the North Sea Basin (pers. obs.) and may be recorded outside northwest Europe in future studies. This form has only previously been recorded from onshore material (Black, 1972; Crux, 1991).

\section{Bownia glabra Interval Range NF Zone (NAL 5) \\ Definition: Interval from LAD of Braloweria boletiformis} to FAD of Ceratolithina bicornuta.

Age: Middle Albian, base subdelaruei MF Subzone to top meandrinus MF Subzone.

Remarks: The Bownia glabra NF Zone yields no FADs in this study and the assemblages show only local changes in the relative abundance of some taxa. Sediments equivalent to NAL 5 are very restricted in occurrence due to the erosion of Middle Albian sediments during the cristatum MF Subzone (Owen, 1975). This NF biozone was not sampled at Folkestone due to the attenuated sequence present at this locality. Sediments equivalent to this NF zone are identified, however, within the Soham borehole. NAL 5 has not been identified in the North Sea Basin.

The LAD of a Repagulum parvidentatum influx is an easily recognized and consistent event occurring within the North Sea Basin. The datum was used by Jakubowski (1987) in the identification of his Repagulum parvidentatum Zone (NLK5).

This event, however, as recorded by Crux (1991) using abundance variations at Munday's Hill is unreliable in 


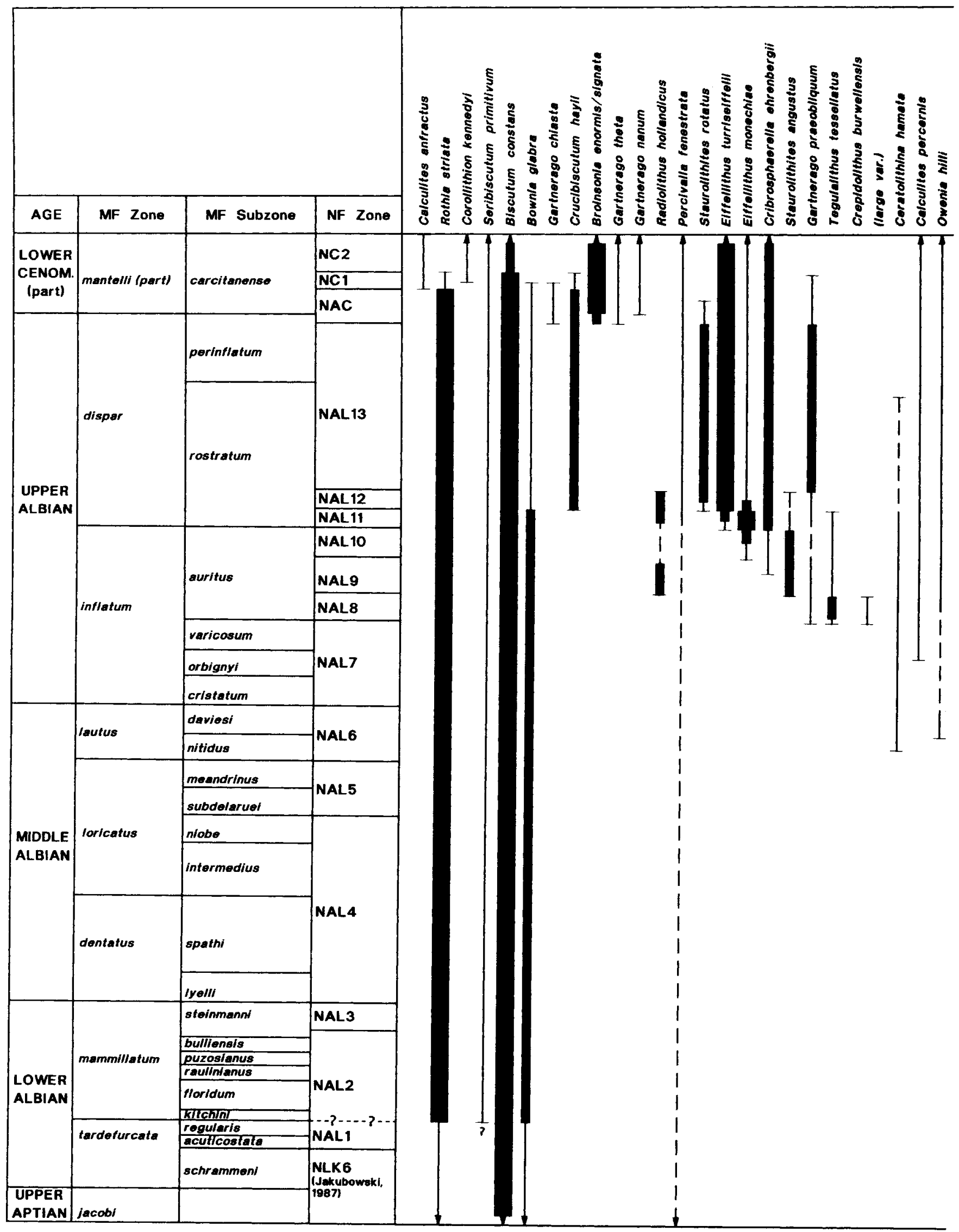

Fig. 19. Composite range chart of stratigraphically important calcareous nannofossils in England and the North Sea Basin: Albian to Lower Cenomanian. 


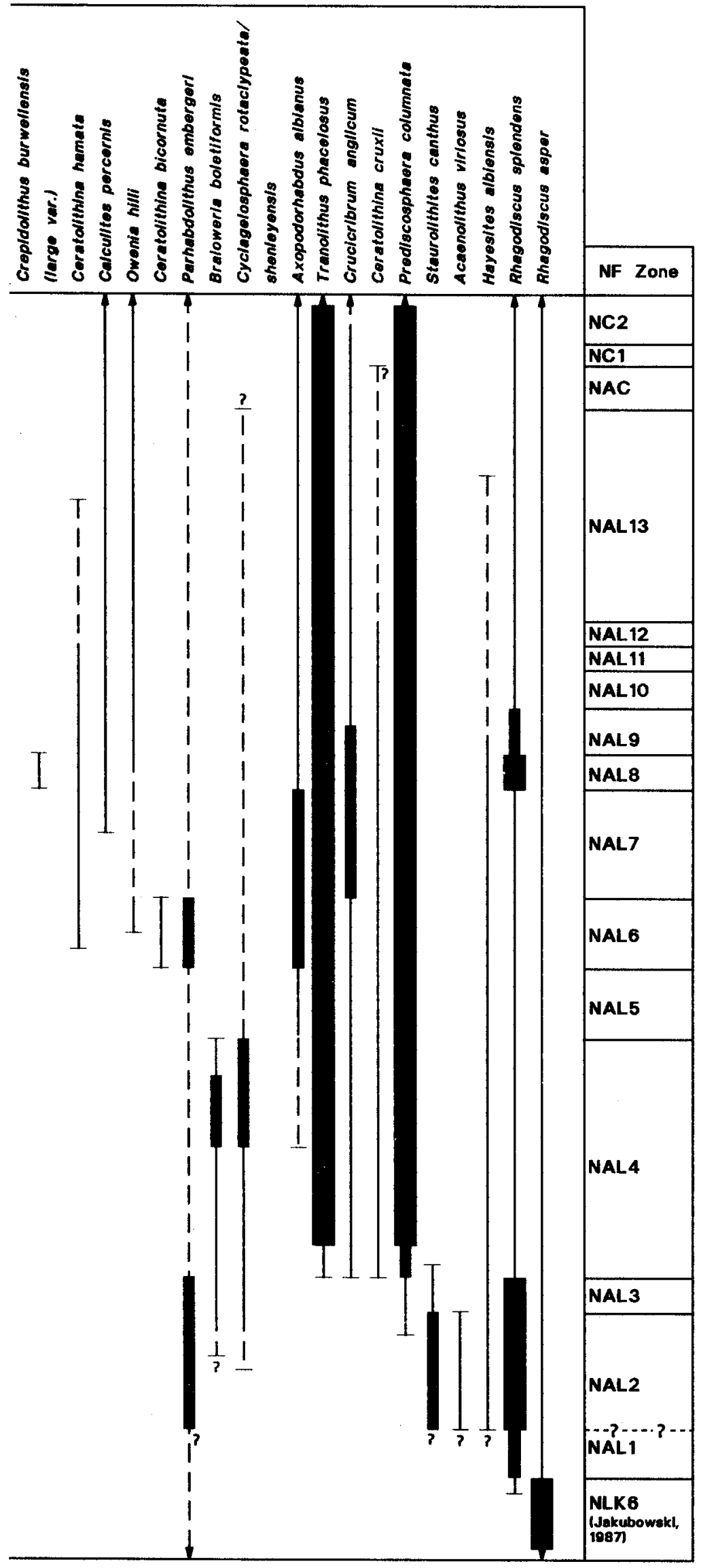

LEGEND

i MFERAED / OUESTIONABLE OCCURREMCE

$I$

RARE / OCCABIONAL OCCURAENCE

$I$

COMMON OCCURAENCE

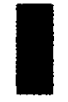

ABUMDANT OCCURRENCE

Note:

Diversity and abundance in North Sea Besin is generally lower than in offshore sections.

Seriblscutum primitivum in Yorkshire and North Sea Basin is abundant from NC1 to base NAL2

tardefurcata and Jacobi MF dated sediments in the North Sea Basin area are generally non-calcareous and barren of nannofossils

Fig. 19. (Continued.) 

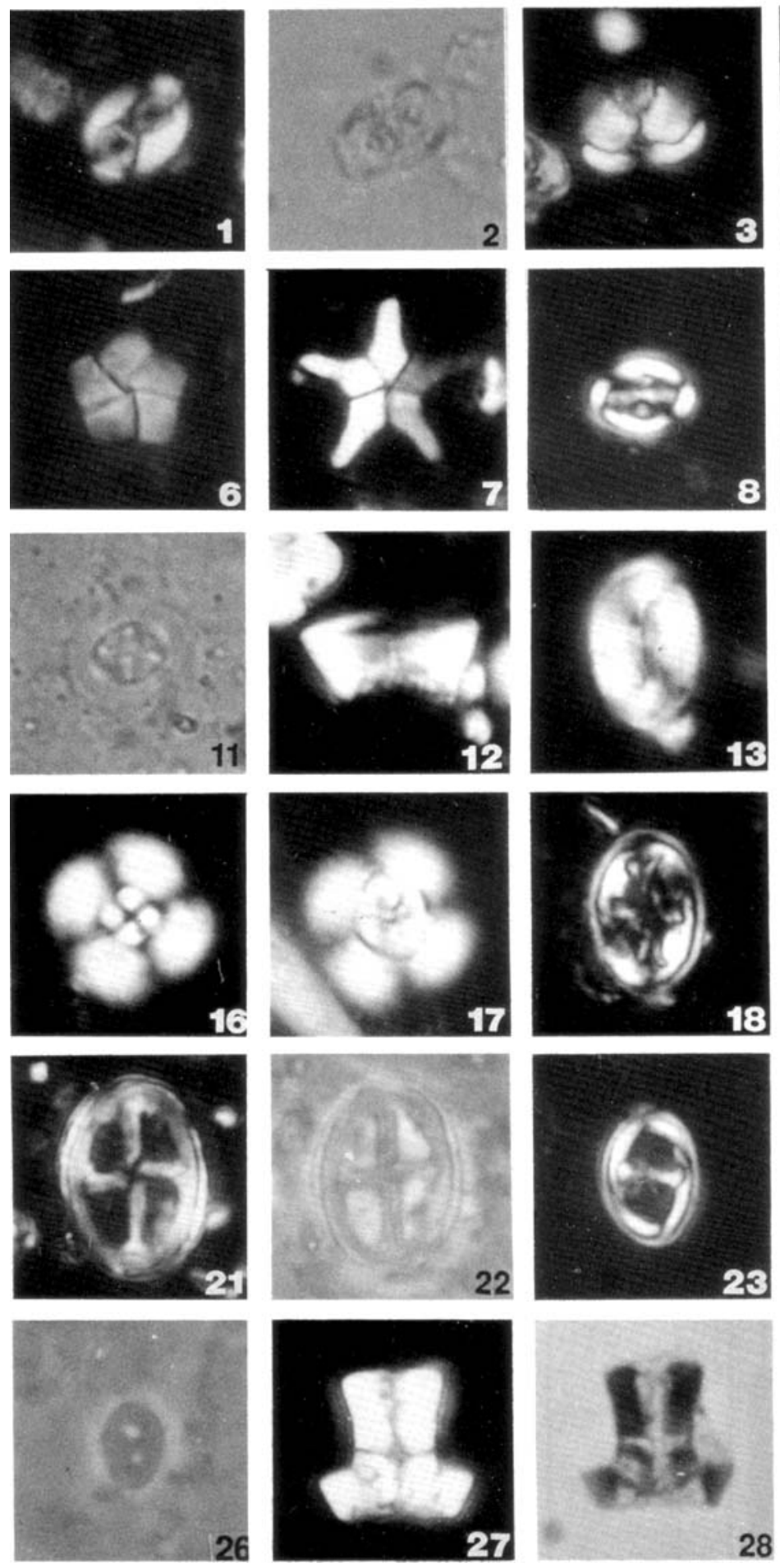
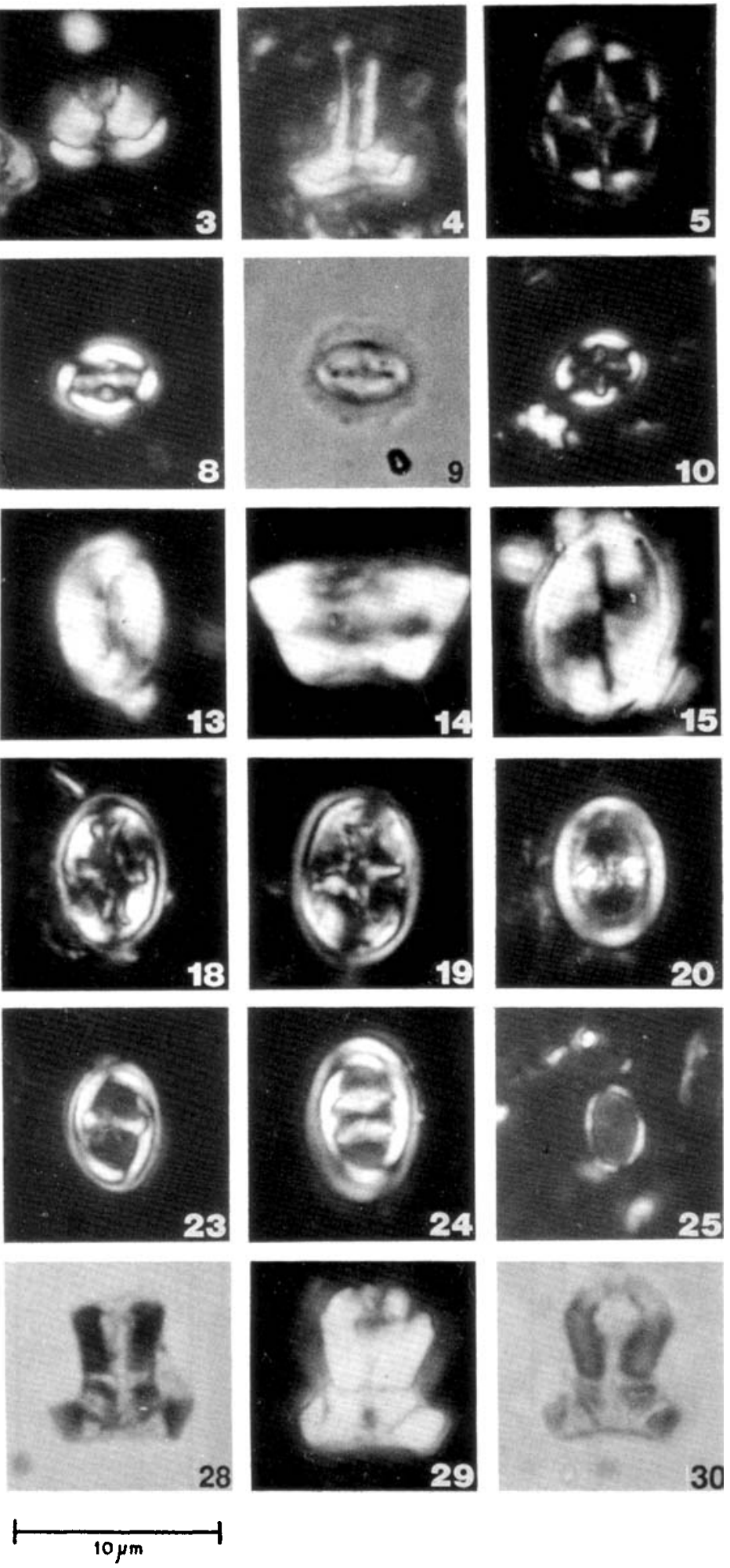

Plate 1 
onshore field sections where $R$. parvidentatum is also a major component of Upper Albian assemblages. This anomaly is possibly a reflection of the normally lower diversity and poorer preservation in offshore material.

\section{Ceratolithina bicornuta Taxon Range NF Zone (NAL 6) \\ Definition: Total range of Ceratolithina bicornuta.}

Age: Middle Albian, base nitidus MF Subzone to top daviesi MF Subzone.

Remarks: Perch-Nielsen (1988) recorded C. bicornuta from Bed VI (nitidus MF Subzone)-Bed VIII (cristatum MF Subzone) at Folkestone. Extensive searching at the type Gault Clay section and at other ammonite-dated sections has, as yet, failed to record this form from above the daviesi MF Subzone. The presence of Ceratolithina hamata in the niobe MF Subzone at Munday's Hill, Bedfordshire, as recorded by Crux (1991), is anomalous possibly due to mis-sampling over the niobe/cristatum stratigraphic break. Sediments equivalent to this NF biozone appear to be very restricted due to a short but widespread period of erosion in the cristatum MF Subzone (Owen, 1975). Ceratolithina bicornuta is rare in offshore wells possibly as a result of the condensed nature or absence of NAL 6 equivalent sediments. Ceratolithina bicornuta has, however, been observed (pers. obs.) in the South Halibut Basin (North Sea).

\section{Ceratolithina hamata Interval Range NF Zone (NAL 7)} Definition: Interval from LAD of Ceratolithina bicornuta to FAD of Tegulalithus tessellatus (and Gartnerago praeobliquum).

Age: Upper Albian, base of cristatum MF Subzone to top varicosum MF Subzone.

Remarks: Due to the absence of the Middle Albian lautus MF Zone over much of the English Albian, the first occurrences of Ceratolithina hamata and Axopodorhabdus albianus are often found at the base of the Late Albian in the cristatum MF Subzone e.g. at Munday's Hill.

Crux (1991) considered the FAD of Owenia hilli as a potential biostratigraphical datum for the basal Upper Albian. In the present study, the FAD of $O$. hilli is recorded earlier within the daviesi MF Subzone.

Hayesites albiensis is confined to Albian sediments below (except for a single identification within the Folkestone borehole) the FAD of Eiffellithus turriseiffelii in this study Hill (1976) and Crux (1991). Many authors including Roth \& Thierstein (1972), Verbeek (1977) and Manivit et al. (1977) used H. albiensis as a zonal marker co-occurring with E. turriseiffelii. $H$. albiensis is considered an unreliable biostratigraphic marker in this study.

Braarudosphaera stenorhetha appears in this NF zone in the southern North Sea where it is associated with common/abundant Braarudospharea primula and Braarudosphaera quinquecostata. The Braarudosphaera assemblage is particularly well developed in East Anglia, Yorkshire and in the southern North Sea. The common/abundant occurrence of the Braarudosphaera group in the orbignyi to varicosum MF Subzones is considered a localized event possibly due to palaeoenvironmental conditions. Hill (1976) recorded a similar event (Braarudosphaera quinquecostata Acme Zone) associated with Eiffellithus turriseiffelii.

Lambert (1986) grouped the separate species of Braarudosphaera under $B$. africana, based on the discovery of entire coccoliths in Albian laminated mudstones from Cameroon. The different architectural forms have not all been grouped under $B$. africana in the present study since they appear to have distinct stratigraphic ranges.

Tegulalithus tessellatus Partial Range NF Zone (NAL 8) Definition: Interval from FAD of Tegulalithus tessellatus (and Gartnerago praeobliquum) to FAD of Staurolithites angustus.

\section{Explanation of Plate 1}

Figs 1-4. Owenia hilli. Fig. 1, crossed-nicols, SMH-10-06; fig. 2, bright field, same specimen, SMH-10-07. Fig. 3, crossed-nicols, partial side view, SMH-14-09. Fig. 4, crossed-nicols, side view, SMH-10-10. All specimens, auritus MF Subzone, Bed 6, Munday's Hill, Bedfordshire (NAL 9). Fig. 5. Axopodorhabdus albianus, crossed-nicols, SMH-13-08, varicosum MF Subzone, Bed X, Copt Point, near Folkestone, Kent (NAL 7). Fig. 6. Braarudosphaera primula, crossed-nicols, SMH-11-30, varicosum MF Subzone, Bed 5, Munday's Hill (NAL 7). Fig. 7. Braarudosphaera stenorhetha, crossed-nicols, SMH-08-05, varicosum MF Subzone, Bed 5, Munday's Hill (NAL 7). Figs 8-9. Crucibiscutum hayi. Fig. 8, crossed-nicols, SMH-16-24; fig. 9, bright field, same specimen, SMH-16-25, mantelli MF Zone, Folkestone Warren borehole, $36.75 \mathrm{~m}$ (NAC). Figs 10-11. Crucibiscutum sp.1. Fig. 10, crossed-nicols, SMH-08-12; fig. 11, bright field, same specimen, SMH-08-13, intermedius MF Subzone, Bed 2, Munday's Hill (NAL 4). Figs 12-13. Crepidolithus burwellensis. Fig. 12, crossed-nicols, SMH-12-20, intermedius MF Subzone, Nine Acres Quarry, Bedfordshire (NAL 4). Fig. 13, crossed-nicols, SMH-09-16, orbignyi MF Subzone, Bed IX, Copt Point (NAL 7). Figs 14-15. Crepidolithus burwellensis (large variety). Fig. 14, SMH-12-23 and fig. 15, SMH-11-35, crossed-nicols, both specimens from Block 15, UK central North Sea (NAL 8). Fig. 16. Cyclagelosphaera rotaclypeata, crossed-nicols, SMH-09-26, intermedius MF Subzone, Bed 2, Munday's Hill (NAL 4). Fig. 17. Cyclagelosphaera shenleyensis, crossed-nicols, SMH-09-27, intermedius MF Subzone, Bed 2, Munday's Hill (NAL 4). Figs 18-19. Eiffellithus monechiae. Fig. 18, crossed-nicols, SMH-12-32, auritus MF Subzone, Bed 6, Munday's Hill (NAL 10). Fig. 19, crossed-nicols, SMF-12-31, rostratum MF Subzone, Bed 17, Burwell, Cambridgeshire (NAL 11). Fig. 20. Zeugrhabdotus noeliae, crossed-nicols, SMH-06-03, daviesi MF Subzone, Bed VII, Copt Point (NAL 6). Figs 21-22. Gartnerago praeobliquum. Fig. 21, crossed-nicols, SMH-11-32; fig. 22, bright field. same specimen, SMH-11-31, auritus MF Subzone, Bed 15, Burwell (NAL 8). Figs 23-24. Lordia xenota. Fig. 23, crossed-nicols, SMH-11-22, spathi MF Subzone, Bed I, Copt Point (NAL 4). Fig. 24, crossed-nicols, SMH-11-18, auritus MF Subzone, Bed 16, Burwell (NAL 9). Figs 25-26. Orastrum perspicuum. Fig. 25, crossed-nicols, SMH-11-04; fig. 26, bright field, same specimen, SMH-11-05, intermedius MF Subzone, Bed II, Copt Point (NAL 4). Note the two perforations which were not described by Varol (1991) due to overgrowth in his material. Figs 27-30. Braloweria boletiformis. Fig. 27, crossed-nicols, SMH-12-17; fig. 28, bright field, same specimen, SMH-12-18, intermedius MF Subzone, Bed 2, Munday's Hill (NAL 4). Fig. 29, crossed-nicols, SMH-10-20: fig. 30, bright field, same specimen, SMH-10-19, intermedius MF Subzone, Nine Acres Quarry (NAL 4). 

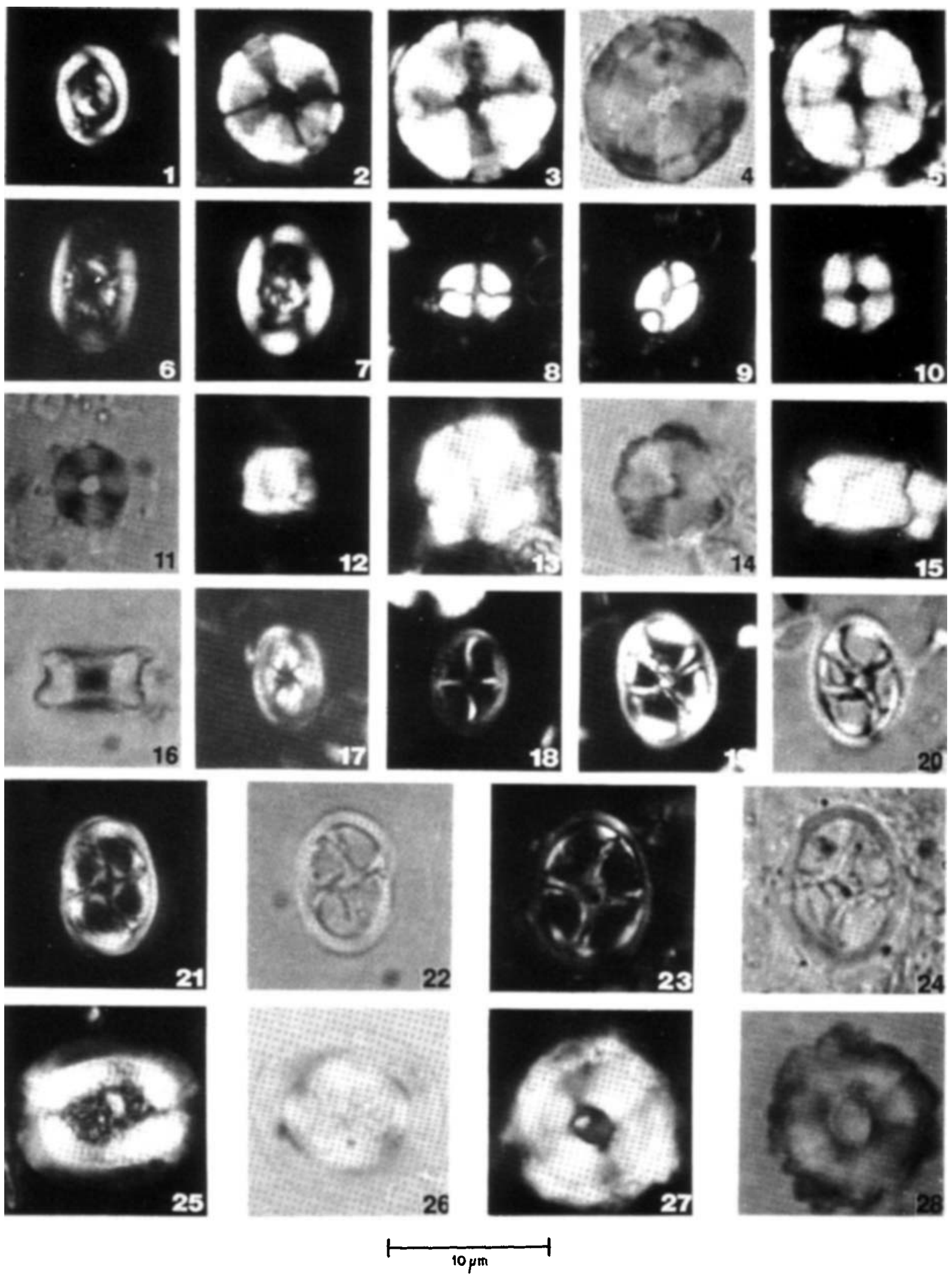

Plate 2 
Age: Upper Albian, auritus MF Subzone (lower part). Remarks: Tegulalithus tessellatus is restricted to this NF biozone in the North Sea Basin but occurs sporadically in younger NF zones from onshore localities. The FAD of $T$. tessellatus is a reliable biostratigraphic event. This form appears at Folkestone towards the base of the auritus MF Subzone together with Gartnerago praeobliquum. This association also occurs at Munday's Hill, Burwell and at La Héve, northern France (pers. obs.), in reliably dated auritus MF Subzonal sediments (J. Eyers, pers. comm.,1993) and is locally present in sequences throughout the North Sea Basin.

\section{Staurolithites angustus Partial Range NF Zone (NAL 9)}

Definition: Interval from FAD of Staurolithites angustus (and Radiolithus hollandicus) to FAD of Eiffellithus monechiae.

Age: Upper Albian, auritus MF Subzone.

Remarks: Staurolithites angustus appears to be a cosmopolitan form having been recorded in Tunisia and Spain (Verbeek, 1977), onshore Holland (Stradner et al., 1968) and northern France (pers. obs.), below the FAD of Eiffellithus turriseiffelii. Staurolithites angustus as described by Stover (1966), has not been found to occur outside the Upper Albian in the present study. The LAD of Braarudosphaera stenorhetha within this NF zone appears to represent a localized event within the southern North Sea and England. Hill (1976) recorded B. stenorhetha from Oklahoma and Texas in younger Albian sediments associated with Eiffellithus turriseiffelii.

\section{Eiffellithus monechiae Partial Range NF Zone (NAL 10)}

Definition: Interval from FAD of Eiffellithus monechiae to FAD of Eiffellithus turriseiffelii.

Age: Upper Albian, auritus MF Subzone (upper part).

Remarks: A minor hiatus at the base of the rostratum MF Subzone has resulted in much of the upper part of the auritus MF Subzone being removed in Cambridgeshire ( $\mathrm{J}$. Eyers, pers. comm., 1993). This hiatus also occurs in the Folkestone section, with a non-sequence represented by phosphatic nodules at the base of the 'Greensand Seam' (Bed XII).

Eiffellithus turriseiffelii Partial Range NF Zone (NAL 11) Definition: Interval from FAD of Eiffellithus turriseiffelii to FAD of Crucibiscutum hayi.

Age: Upper Albian, rostratum MF Subzone (lower part).

Remarks: This NF zone contains a period of nannofloral diversification characterized by the rapid evolution of the Eiffellithaceae. This evolutionary lineage has previously been documented by many authors, e.g. Verbeek (1977) and Hill \& Bralower (1987). A similar evolutionary trend exists between Staurolithites angustus and Staurolithites rotatus within this NF biozone, whereby the bars which were near parallel to the axes of the ellipse rotated to form large angles with the axes.

The FAD of E. turriseiffelii has been used as a zonal marker event by many authors, e.g. Roth (1973), Thierstein (1976), Sissingh (1977), Taylor (1982) and Jakubowski (1987).

The FAD of abundant Eiffellithus monechiae is an alternative marker for the base of NAL 11 .

\section{Radiolithus hollandicus Partial Range NF Zone (NAL 12)}

Definition: Interval from FAD of Crucibiscutum hayi to LAD of Radiolithus hollandicus.

Age: Upper Albian, rostratum MF Subzone.

Remarks: Radiolithus hollandicus occurs as distinct influxes at disparate stratigraphic levels and can be missed in field samples, sidewall cores or core samples. Its LAD in ditch cuttings, however, is a recognized correlatable event in North Sea wells.

Eiffellithus monechiae is subordinate to E. turriseiffelii within this biozone.

Crux (1991) identified Crucibiscutum hayi throughout the Middle to Upper Albian section at Munday's Hill, Bedfordshire. A review of these sediments, however, resulted in the identification of a variety of Crucibiscutum spp. from the Middle Albian which are not synonymous with

\section{Explanation of Plate 2}

Fig. 1. Braloweria boletiformis, crossed-nicols, SMH-13-29, niobe MF Subzone, Bed 3(iii), Munday's Hill, Bedfordshire (NAL 4). Figs 2-4. Radiolithus hollandicus (11 rayed form). Fig. 2, crossed-nicols, SMH-10-27, auritus MF Subzone, Bed 16, Burwell, Cambridgeshire (NAL 9). Fig. 3, crossed-nicols, SMH-12-09; fig. 4, bright field, same specimen, SMH-12-10, auritus MF Subzone, Bed 6, Munday's Hill (NAL 9). Fig. 5. Radiolithus hollandicus (12 rayed form), crossed-nicols, SMH-12-06, auritus MF Subzone, Bed 16, Burwell (NAL 9). Fig. 6. Rhagodiscus splendens, crossed-nicols SMH-15-23, auritus MF Subzone, Bed 16, Burwell (NAL 9). Fig. 7. Rhagodiscus asper, crossed-nicols, SMH-04-01, intermedius MF Subzone, Bed 2, Munday's Hill (NAL 4). Figs 8-9. Calculites percernis. Fig. 8, crossed-nicols, SMH-12-05, holotype; fig. 9, crossed-nicols, SMH-12-04, same specimen, auritus MF Subzone, Bed 16, Burwell (NAL 9). Figs 10-16, 27-28. Tegulalithus tessellatus. Fig. 10, crossed-nicols, SMH-14-01; fig. 11, bright field, same specimen, SMH-14-02, auritus MF Subzone, Bed 15, Burwell (NAL 8). Fig. 12, crossed-nicols, SMH-14-07, auritus MF Subzone, Bed 6, Munday's Hill (NAL 8). Fig. 13, crossed-nicols, SMH-09-09; fig. 14, bright field, same specimen, SMH-09-08, auritus MF Subzone, Bed XI, Copt Point, Kent (NAL 8). Fig. 15, crossed-nicols, SMH-14-05; fig. 16, bright field, same specimen, SMH-14-06, auritus MF Subzone, Soham borehole, Cambridgeshire, sample No. 3309 (NAL 8). Fig. 27, crossed-nicols, SMH-09-12; fig. 28, bright field, same specimen, SMH-09-11, auritus MF Subzone, Bed 6, Munday's Hill (NAL 8). Fig. 17. Bukrylithus ambiguus, crossed-nicols, SMH-17-21, niobe MF Subzone, Bed III, Copt Point (NAL 4). Fig. 18. Staurolithites gausorhethium, crossed-nicols, SMH-09-22, auritus MF Subzone, Bed 16, Burwell (NAL 8). Figs 19-20. Staurolithites rotatus. Fig. 19, crossed-nicols, SMH-16-30, holotype; fig. 20, bright field, same specimen, SMH-16-31, dispar MF Zone, Bed XIII, Copt Point (NAL 13). Figs 21-24. Staurolithites angustus. Fig. 21, crossed-nicols, SMH-10-31; fig. 22, bright field, same specimen, SMH-10-30, auritus MF Subzone, Bed XI, East Wear Bay, Kent (NAL 9). Fig. 23, crossed-nicols, SMH-12-26; fig. 24, bright field, same specimen, SMH-12-27, auritus MF Subzone, Bed 6, Munday's Hill (NAL 9). Figs 25-26. Gaarderella granulifera. Fig. 25, crossed-nicols, SMH-11-20; fig. 26, bright field, same specimen, SMH-09-11, intermedius MF Subzone, Bed 2, Munday's Hill (NAL 4). 

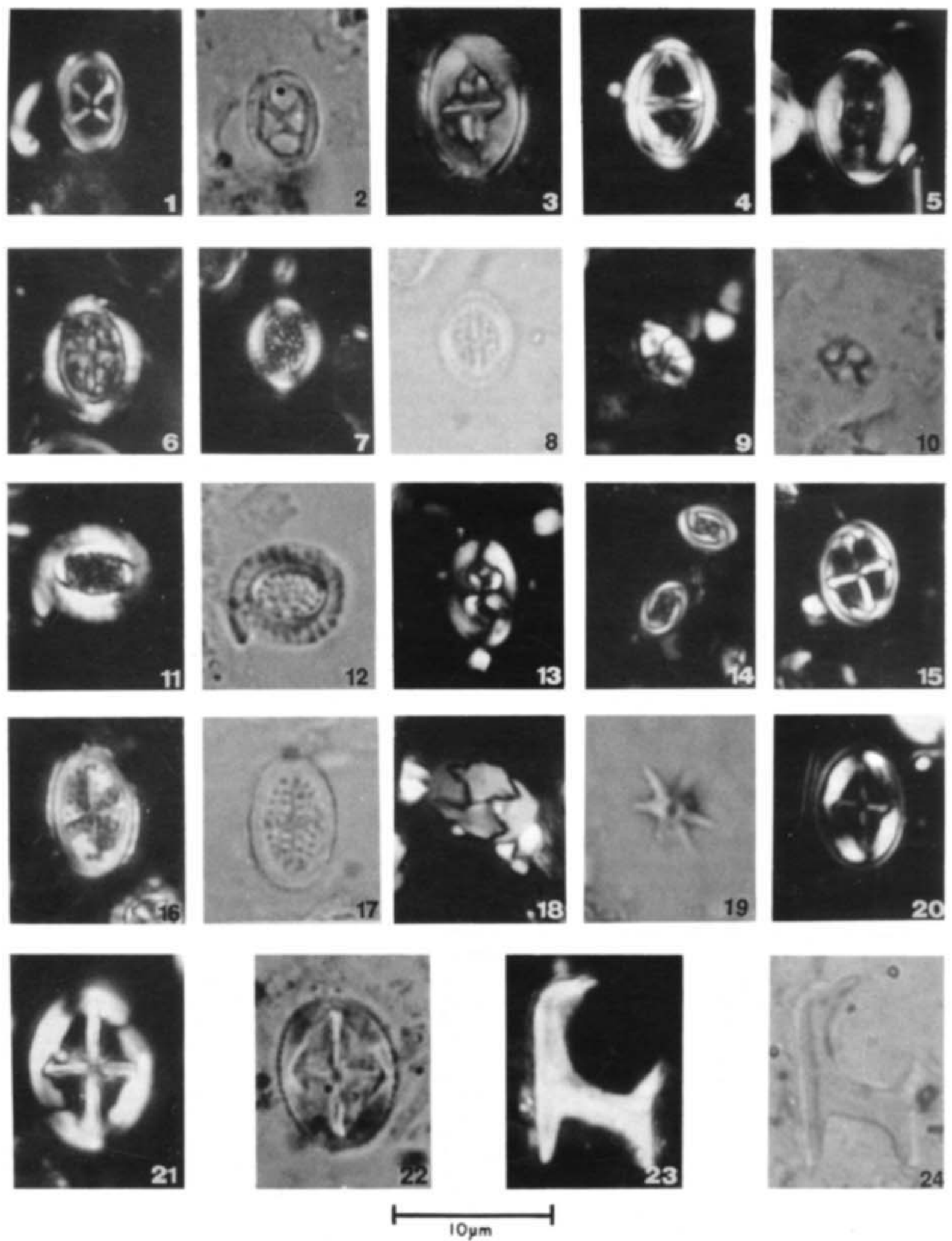

Plate 3 
C. hayi s.s, e.g. Crucibiscutum sp. 1 (Pl. 1, Figs 10, 11). A form very similar to $C$. hayi is also present in Upper/Middle Aptian sediments from the North Sea Basin. This Crucibiscutum sp. is, however, probably more closely related to Crucibiscutum salebrosum. Electron microscopical analysis is needed to resolve the problem. In this study, C. hayi s.s does not appear until the rostratum MF Subzone.

This NF biozone equates in part to the Gartnerago praeobliquum NF Zone (NLK4) of Jakubowski (1987). This NF zone was defined as Middle to Upper Albian in age without any reference to ammonite-dated material.

\section{Gartnerago praeobliquum Interval Range NF Zone (NAL 13)}

Definition: Interval from L.AD of Radiolithus hollandicus to FAD of common/abundant Broinsonia enormis.

Age: Upper Albian, rostratum-perinflatum MF Subzones.

Remarks: This stratigraphic level has been correlated to a transgression within the dispar MF Zone (Eyers, 1992). In England, this sea-level rise is expressed by monotonous, very pale grey clays, with little evidence of breaks in sedimentation, unlike the underlying Gault Clay which is usually darker in colour and punctuated by numerous stratigraphic breaks.

The nannoflora within this NF biozone exhibit a degree of provincialism. Crucibiscutum hayi, Cribrosphaerella ehrenbergii, Percivalia fenestrata and Staurolithites rotatus are characteristic components of this NF zone in England and the southern North Sea but are rare in the central and northern North Sea.

\section{Broinsonia enormis Partial Range NF Zone (NAC)}

Definition: Interval from FAD of common/abundant Broinsonia enormis to FAD of Calculites anfractus.

Age: Upper Albian, perinflatum MF Subzone 'Lowermost' Cenomanian, carcitanense MF Subzone (lower part).

Remarks: In southern England NAC has only been found to correlate with macrofossil dated sediments of 'lowermost' Cenomanian age. A regional non-sequence is present at the Albian/Cenomanian boundary in northern France and southern Britain. An expanded ammonite dated equivalent of this NF biozone (Upper Albian to Lower Cenomanian) is preserved in the Vocontian Trough (A. S. Gale, pers. comm., 1994). A thick development of NAC dated sediments are also present in the Red Chalk of Speeton (pers. obs.). It is plausible that at Speeton, unlike in southern Britain, a complete Albian to Cenomanian boundary succession is present. Unfortunately, ammonite data are extremely sparse and the Cenomanian/Albian boundary is difficult to accurately locate (H. G. Owen, pers. comm., 1994).

The nannoflora at Mt. Risou does not exhibit any marked assemblage changes over the Albian/Cenomanian boundary. The FAD of Gartnerago nanum is of potential importance but further work is required to prove its value as a boundary marker. Gartnerago chiasta is present in the Vocontian Trough, England and southern North Sea but does not appear to have migrated any further north.

\section{Rothia striata Partial Range NF Zone (NC 1) \\ Definition: Interval from FAD of Calculites anfractus to LAD of Rothia striata.}

Age: 'Lowermost' Cenomanian, mantelli MF Zone (lower part).

Remarks: This NF zone equates in part to the Phanulithus anfractus (NLK1), Seribiscutum primitivum (NLK 2), Hemipodorhabdus gorkae (NLK 3) and Gartnerago praeobliquum (NLK 4) NF Zones of Jakubowski (1987).

The LAD of abundant Biscutum constans approximates to the top of NC1 in the central North Sea. This event is, however, diachronous and found in younger sediments from onshore localities and in well sections from the North Viking Graben (Northern North Sea).

Seribiscutum primitivum is abundant at this stratigraphic level in the North Sea Basin and Yorkshire but is a minor component of nannofloral assemblages in southern Britain. At the Mt Risou section, $S$. primitivum is absent from the majority of samples analysed.

\section{Explanation of Plate 3}

Figs 1-2. Gartnerago chiasta. Fig. 1, crossed-nicols, SMH-16-27; fig. 2, bright field, same specimen, SMH-16-28, ?mantelli MF Zone, Wilstone Reservoir, near Tring, Buckinghamshire (NC 1). Fig. 3. Gartnerago nanum, crossed-nicols, SMH-06-11, Dutch southern North Sea, Upper Holland Marl, Well Q/7-2 (NAC). Fig. 4. Gartnerago theta, crossed-nicols, SMH-16-22, Dutch southern North Sea, Upper Holland Marl, Well Q/7-2. (NAC). Fig. 5. Percivalia fenestrata, crossed-nicols, SMH-02-01, rostratum MF Subzone, Arlesey, Bedfordshire (NAL 13). Fig. 6. Cretarhabdus inaequalis (large variety), crossed-nicols, SMH-16-12, Bed A5, ewaldi Marl, Speeton, Yorkshire (NAL 2). Figs 7-8. Cretarhabdus inaequalis. Fig. 7, crossed-nicols, SMH-11-13; fig. 8, bright field, same specimen, SMH-11-14, orbignyi MF Subzone, Bed IX, Copt Point, Kent (NAL 7). Figs 9-10. Calculites dispar. Fig. 9, crossed-nicols, SMH-17-08; fig. 10, bright field, same specimen, Bed A3, Speeton (NAL 3). Note the four perforations in this form were not originally described by Varol (1991), due to overgrowth in his material. Figs 11-12. Cribrosphaerella ehrenbergii. Fig. 11, crossed-nicols, SMH-16-32; fig. 12, bright field, same specimen, SMH-16-33, rostratum-perinfatum MF Subzones, Bed XIII, Copt Point (NAL 13). Fig. 13. Rothia striata, crossed-nicols, SMH-13-21, Hunstanton Formation, South Ferriby, Humberside (NAL 7). Fig. 14. ?Lordia xenota (small variety), crossed-nicols, SMH-11-17, intermedius MF Subzone, Bed I, Copt Point (NAL 4). Fig. 15. Staurolithites canthus, crossed-nicols, SMH-16-09, Bed A5, ewaldi Marl, Speeton, holotype (NAL 2). Figs 16-17. Crucicribrum anglicum. Fig. 16, crossed-nicols, SMH-12-01; fig. 17, bright field, same specimen, SMH-12-02, varicosum Subzone, Bed 5, Munday's Hill, Bedfordshire (NAL 7). Fig. 18. Calculites anfractus, crossed-nicols, SMH-04-36, ?mantelli MF Zone, Tring (NC 1). Fig. 19. Hayesites albiensis, bright field, SMH-07-19, intermedius MF Subzone, Nine Acres Quarry, Bedfordshire (NAL 4). Fig. 20. Bownia glabra, crossed-nicols, SMH-17-36, daviesi MF Subzone, Bed VII, Copt Point, holotype (NAL 6). Figs 21-22. Acaenolithus viriosus. Fig. 21, crossed-nicols, SMH-17-04, Bed A5, ewaldi Marl, Speeton, holotype (NAL 2). Fig. 22, bright field, SMH-17-05, Dutch southern North Sea, Middle Holland Shale Member, Well Q/16-2 (NAL 2). Figs 23-24. Ceratolithina bicornuta. Fig. 23, crossed-nicols, SMH-08-08; fig. 24, bright field, same specimen, SMH-08-07, daviesi MF Subzone, Bed VII, Copt Point (NAL 6). 

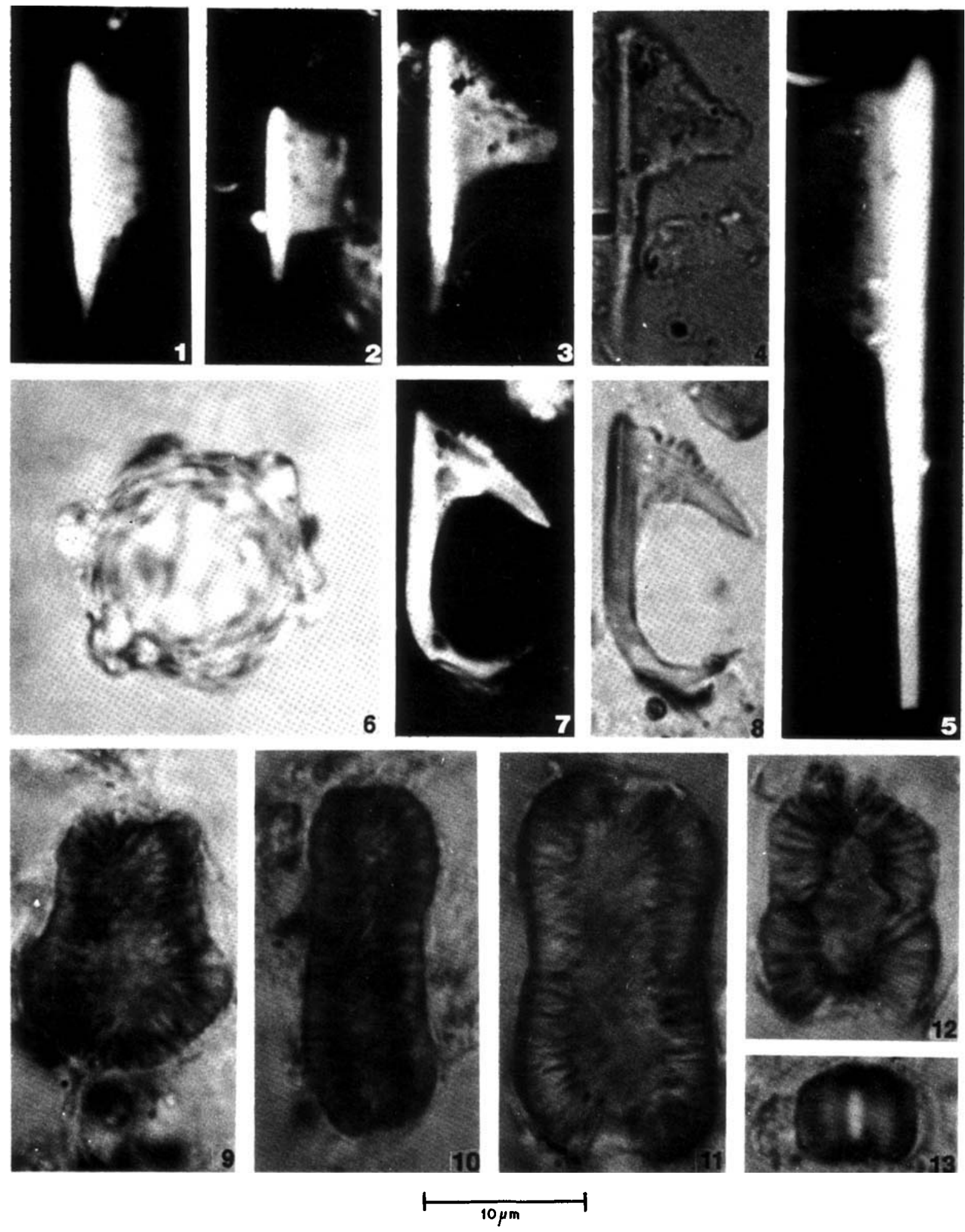

Plate 4 
Calculites anfractus Partial Range NF Zone (NC 2)

Definition: Interval from LAD of Rothia striata to LAD of Calculites anfractus.

Age: Lower Cenomanian, mantelli MF Zone.

\section{TAXONOMY}

A detailed taxonomic section is not provided, although taxa referred to in this paper are listed alphabetically in Appendix 1. Taxonomic references not included in the reference list can be found in Perch-Nielsen (1985). New species and combinations are detailed below.

\section{Genus ACAENOLITHUS Black, 1973 Acaenolithus viriosus sp. nov.}

(Pl. 3, figs. 21-22)

Derivation of name: Latin viriosus, meaning robust. Diagnosis: A large species of Acaenolithus with large central openings and a massive unstriated cross. The outline of the coccolith is elliptical with a rim built of two separate shields. The distal surface of the rim is fluted. The central opening is spanned by a robust cross along the principal axes of the ellipse. A short spine is present at the centre. On the proximal side, each arm of the cross appears to have a shallow central furrow.

Holotype: SMH-17-04 (Pl. 3, fig. 21).

Type locality and horizon: Speeton, Yorkshire, ewaldi Marl, Bed $A_{5}$ (Early Albian).

Dimensions: Mean length $-8.9 \mu \mathrm{m}, 50$ specimens measured. Maximum length $-11.8 \mu \mathrm{m}$. Smallest forms appear to grade into $A$. galloisii (mean length of $5.5 \mu \mathrm{m}$ ). Forms with a maximum length of greater than $8 \mu \mathrm{m}$ are assigned to A.viriosus.

Remarks: Acaenolithus viriosus appears to be constructed similarly to $A$. galloisii when viewed under the light microscope. Acaenolithus viriosus is, however, much larger. A similar form to A. viriosus, although possessing a more elaborate rim structure, occurs in the Glauconitic Marl at Folkestone and is possibly synonymous to ' $A$. cenomanicus Black (1973).

\section{Genus BOWNIA Varol, 1994 Bownia glabra sp. nov.}

(Pl. 3, fig. 20)

1966 Coccolithus matalosus Stover: 139, pl. 2; pl. 8, fig. 10. 1973 Vagalapilla matalosa (Stover) Thierstein: 37-38, pl. 3, figs 15-18.

1994 Bownia matalosa (Stover) Varol \& Girgis: 237, fig. 11,1 .
Derivation of name: Latin glabra, meaning smooth.

Diagnosis: The coccoliths are elliptical and consist of two closely-appressed zeugoid walls. The central opening is bridged by a narrow cross parallel to the principal axes of the ellipse with flaring, arrowhead-like ends. Under crossed-nicols, the inner cycle is highly birefringent and appears brighter than the rim.

Holotype: SMH-17-36 (Pl. 3, fig. 20).

Type locality and horizon: Speeton, Yorkshire, ewaldi Marl, Bed As (Early Albian).

Dimensions: L: $6-8 \mu \mathrm{m}$ (mean length $7.5 \mu \mathrm{m}$ ), 50 specimens measured.

Remarks: Stover's holotype, (PI. 2, figs 1a-c) clearly exhibits a scalloped outer rim, similar to that of the Arkhangelskiellaceae, and is probably synonymous with Broinsonia signata or Acaenolithus cenomanicus.

Stover's paratype, (Pl. 2, figs $2 \mathrm{a}-\mathrm{b}$ ) has a zeugoid outer wall and is identifiable as Bownia glabra.

Genus CALCULITES Prins \& Sissingh in Sissingh, 1977 Calculites percernis sp. nov.

(Pl. 2, figs. 8-9)

1976 Biscutum supracretaceum Hill: 124 , Pl. 2, figs 1-9.

1991 Calculites sp. 1 Crux: 214, Pl. 1, fig. 4; Pl. 2, figs 5-6.

Derivation of name: Latin percernis, meaning easily visible.

Diagnosis: This holococcolith is composed of a narrow rim, a broad wall consisting of a limited number of calcite blocks and a central pore. Under crossed-nicols and with the axes of the ellipse aligned with the nicols, extinction gyres lie on the principal axes of the ellipse. With the axes rotated 45 degrees to the nicols, the gyres do not intersect but form arches about the acute ends of the ellipse.

Holotype: SMH-12-05 (Pl. 2, fig. 8).

Type locality and horizon: Burwell, Cambridgeshire, Bed 16 (Late Albian).

Dimensions: L: $3-5 \mu \mathrm{m}$ (mean length $4.4 \mu \mathrm{m}$ ), 50 specimens measured.

Remarks: This small holococcolith is abundant at certain horizons within the auritus MF Subzone in Cambridgeshire and Bedfordshire and in the dispar MF Zone of the Vocontian Trough, France (pers. obs.).

\section{Genus CRUCIBISCUTUM Jakubowski, 1986 Crucibiscutum sp. 1}

(P1. 1, figs 10-11)

Remarks: A species of Crucibiscutum with an asymmetrical cross.

\section{Explanation of Plate 4}

Figs 1-5. Ceratolithina cruxii. Fig. 1, crossed-nicols, SMH-11-09. Fig. 2, crossed-nicols, SMH-11-06. Fig. 3, crossed-nicols, SMH-09-17; fig. 4, bright field, same specimen, SMH-09-19. Fig. 5, crossed-nicols, SMH-11-07. All specimens, intermedius MF Subzone, Bed 2, Munday's Hill, Bedfordshire (NAL 4). Fig. 6. Cyclagelosphaera shenleyensis (coccosphere), bright field, SMH-11-29, intermedius MF Subzone, Bed 2, Munday's Hill (NAL 4). Figs 7-8. Ceratolithina hamata. Fig. 7, crossed-nicols, SMH-09-15; fig. 8, bright field, same specimen, SMH-09-14, orbignyi MF Subzone, Bed 4 (iii), Munday's Hill (NAL 7). Fig. 9. Nannoconus aquitanicus, bright field, SMH-08-15, orbignyi MF Subzone, Bed 4 (v), Munday's Hill (NAL 7). Fig. 10. Nannoconus elongatus, bright field, SMH-09-07, auritus MF Subzone, Soham borehole, Cambridgeshire (NAL 8). Fig. 11. Nannoconus grandis, bright field, SMH-08-21, auritus MF Subzone, Bed 6, Munday's Hill (NAL 8). Fig. 12. Nannoconus aff. N. multicadus, bright field, SMH-09-04, auritus MF Subzone, Bed 6, Munday's Hill (NAL 8). Fig. 13. Nannoconus truitti, bright field, SMH-109-05, daviesi MF Subzone, Soham borehole (NAL 6). 
Genus STAUROLITHITES Caratini, 1963 Staurolithites canthus sp. nov.

\author{
(Pl. 3, fig. 15)
}

Derivation of name: Latin canthus, meaning cart-wheel.

Diagnosis: A species of Staurolithites whose central cross is slightly offset from the principal axes of the ellipse. The two cycles forming the rim can be seen with the light microscope between crossed-nicols. The inner cycle is bright and often appears segmented when rotated under crossed-nicols.

Holotype: SMH-16-09 (Pl. 1, fig. 15).

Type locality and horizon: Speeton, Yorkshire, ewaldi Marl, Bed $A_{5}$ (Early Albian).

Dimensions: L: $6-8 \mu \mathrm{m}$ (mean length $7.2 \mu \mathrm{m}$ ), $\quad 50$ specimens measured.

Staurolithites rotatus $\mathrm{sp}$. nov.

(Pl. 2, figs 19-20)

Derivation of name: Latin rotatus, meaning to turn around.

Diagnosis: This form is elliptical with a narrow, single zeugoid wall. The large central opening is bridged by a spine-bearing cross which is often missing. Each bar of the cross consists of two parallel blocks. The bars, unlike in Staurolithites angustus, form a large angle with the long axis of the ellipse. Staurolithites rotatus exhibits a slight bifurcation at the ends of the cross.

Holotype: SMH-16-30 ( P1. 2, fig. 19).

Type locality and horizon: Folkestone, Kent, Bed XIII (Late Albian - dispar MF Zone)

Dimensions: L: $6.5-9 \mu \mathrm{m}$ (mean length $8.5 \mu \mathrm{m}$ ), $\quad 50$ specimens measured.

Remarks: An evolutionary trend is considered to exist between $S$. angustus through intermediate forms to $S$. rotatus where by a gradual rotation of the bars occurs, from almost parallel to the axes of the ellipse to a position midway between the axes of the ellipse. This gradual change has also been documented by Stover (1966) and Verbeek (1977), although they did not differentiate the two end members.

\section{CONCLUSIONS}

Extensive sampling of Albian to Lower Cenomanian, ammonite dated localities, mainly from England, has provided an opportunity to develop a high resolution nannofossil biozonation scheme. A total of sixteen zones are defined.

The Repagulum parvidentatum (NAL 1) and Acaenolithus viriosus (NAL 2) NF Zones are poorly represented in onshore English sections possibly due to unfavourable, high energy, shallow marine environments. Exceptions include Beds A5 to A3 at Speeton and the Chamberlain's Barn section, Bedfordshire, which confirms NAL 2 as Lower Albian in age. The Bownia glabra (NAL 5) and Ceratolithina bicornuta (NAL 6) NF Zones of Middle Albian age are poorly represented at English sections and in the North Sea Basin as a result of the regional Upper Albian cristatum MF erosive event.
A major unconformity is present at the Albian/Cenomanian boundary in southern England with the dispar MF Zone truncated to varying levels. A complete sequence across the boundary is present at Mt. Risou, southern France and possibly in the Red Chalk facies of Yorkshire and the southern North Sea Basin.

\section{ACKNOWLEDGEMENTS}

I would like to thank Dr. J. Eyers (Open University, Milton Keynes), Dr. H. G. Owen (Natural History Museum, London) and Dr. A. S. Gale (Natural History Museum, London) for help in collecting samples and helpful observations on ammonite stratigraphy. I would also like to thank Dr. J. A. Burnett (University College London), $\mathrm{Mr}$ M. Jakubowski (Natural History Museum, London), Dr. J. Crux (Caraças) and Dr. J. R. Young (Natural History Museum, London) for their constructive comments on an earlier draft of the paper. Mr N. Sharp (Shell U.K) is gratefully acknowledged for his help in constructing Figs 2-16. I thank Shell UK for permission to publish this paper.

\section{REFERENCES}

Al-Rifaiy, I., Varol, O. \& Lemone, D. 1990. Middle to Late Albian biostratigraphy of the Cuchillo Formation from Sierra de Sapello, Mexico. Newsletters on Stratigraphy, 21: 187-200.

Amédro, F., Damotte, R., Magniez-Jannin, F. \& Manivit, H. 1981. Échelles biostratigraphiques dans l'Albien due Boulonnais (Macro-Micro-Nannofossiles). Bulletin d'information des geologues du Bassin de Paris, 18: 3-19.

Amédro, F. 1994. Correlations dans les Craies Cenomaniennes traversées par le tunnel sous la Manche (Cote France). Bulletin trimestriel de la Société Géologique de Normandie et des Amis du Muséum du Havre, 81(1): 11-44.

Applegate, J. L., Bergen, J. A., Mitchener Covington, J. \& Wise, S. W. Jr. 1989. Lower Cretaceous nannofossils from continental margin drill sites off north Carolina (DSDP Leg 93) and Portugal (ODP Leg 103): a comparison. In Crux, J. A., \& Heck, S. E. van (Eds), Nannofossils and their Applications, 143-211. Ellis Horwood Ltd., Chichester, for British Micropalaeontological Society.

Black, M. 1971. Coccoliths of the Speeton Clay and Sutterby Marl. Proceedings of the Yorkshire Geological Society, 38(3): 381-424.

Black, M. 1972. British Lower Cretaceous coccoliths. I. Gault Clay. Monograph of the Palaeontographical Society, 1: 1-48.

Black, M. 1973. British Lower Cretaceous coccoliths. I. Gault Clay. Monograph of the Palaeontographical Society, 2: 49-112.

Black, M. 1975. British Lower Cretaceous coccoliths. I. Gault Clay. Monograph of the Palaeontographical Society, 3: 113-142.

Black, M. \& Barnes, B. 1959. The structure of coccoliths from the English Chalk. Geological Magazine, 96(5): 321-328.

Carter, D. J. \& Hart, M.B. 1977. Aspects of mid-Cretaceous stratigraphical micropalaeontology. Bulletin of the British Museum (Natural History), 29(1): 1-135.

Casey, R. 1961. The Stratigraphical Palaeontology of the Lower Greensand. Palaeontology, 3: 487-621, pls. 77-84.

Cepek, P. 1982. Das kalzitische Nannoplankton des späten Apt und frühen Alb (Parhabdolithus angustus-Zone) des Gebietes von Hannover. Geologisches Jahrbuch, A65: 283-306.

Cepek, P. \& Hay, W. W. 1969. Calcareous nannoplankton and biostratigraphic subdivision of the Upper Cretaceous. Transactions of the Gulf Coast Association of Geological Societies, 19: $323-336$

Crux, J. A. 1986. Tegulalithus a new genus of Early Cretaceous calcareous nannofossils. International Nannofossil Association Newsletter, 8: 88-90. 
Crux, J. A. 1987. Six new species of calareous nannofossils from the Lower Cretaceous strata of England and Germany. International Nannofossil Association Newsletter, 9: 30-35.

Crux, J. A. 1991. Albian calcareous nannofossils from the Gault Clay of Munday's Hill (Bedfordshire, England). Journal of Micropalaeontology, 10(2): 203-222.

Doeven, P. H. 1983. Cretaceous nannofossil stratigraphy and paleoecology of the Canadian Atlantic Margin. Bulletin of the Geological Survey of Canada, 356: 1-70.

Eyers, J. 1992. Lithostratigraphy of the Lower Greensand and Gault (Lower Cretaceous) of the Bedfordshire Province, England. Open University, unpublished thesis.

Gallois, R. W. \& Morter, A. A. 1982. The stratigraphy of the Gault of East Anglia. Proceedings of the Geologists 'Association, 93(4): $351-368$.

Grün, W. \& Allemann, F. 1975. The Lower Cretaceous of Caravaca (Spain): Berriasian calcareous nannoplankton of the Miravetes Section (Subbetic Zone, Prov. of Murcia). Eclogae geologicae Helvetiae, 68: 147-211.

Hill, M. E. 1976. Lower Cretaceous calcareous nannofossils from Texas and Oklahoma. Palaeontographica Abteilung $B$, Palaophytologie, 156: 103-179.

Hill, M. E. \& Bralower, T. 1987. Early Evolution, Stratigraphy and Taxonomy of Eiffellithus eximius and Closely-Related Species. Abhandlungen der Geologischen Bundesanstalt (Wien), 39: 89-97.

Jakubow'ski, M. 1986. New calcareous nannofossil taxa from the Lower Cretaceous of the North Sea. International Nannoplankton Association Newsletter, 9: 52-53.

Jakubowski, M. 1987. A proposed Lower Cretaceous calcareous nannofossil zonation scheme for the Moray Firth area of the North Sea. Abhandlungen der Geologischen Bundesanstalt (Wien), 39: 99-119.

Jukes-Browne, A. J. \& Hill, W. 1900. The Cretaceous Rocks of Britain. I The Gault and Upper Greensand of England. Memoirs of the Geological Survey of the United Kingdom, 1-499.

Kaye, P. 1964. Observations on the Speeton Clay (Lower Cretaceous). Geological Magazine, 101: 340-356.

Kemper, E. 1982. Das späte Apt und frühe Alb Nordwestdeutschlands-Versuch der umfassenden Analyse einer Schichtenfolge. Geologisches Jahrbuch, A65: 1-703.

Kemper, E. \& Zimmerle, W. 1978. Der Grenz-Tuff Apt/Alb von Vöhrum. Geologisches Jahrbuch, A45: 125-143.

Lambert, B. 1986. The species notion within the Genus Braarudosphaera Deflandre, 1947. Myth and reality. Revue de Micropaléontologie, 28(4): 255-264.

Lamplugh, G. W. 1922. On the Junction of Gault and Lower Greerisand near Leighton Buzzard (Bedfordshire). Quarterly Journal of the Geological Society of London, 59: 234-265, pls. $16-18$.

Lamplugh, G. W. 1924. A review of the Speeton Clays. Proceedings of the Yorkshire Geological Society, 20: 1-31

Manivit. H., Perch-Nielsen, K., Prins, B. \& Verbeek, J. W. 1977. Mid Cretaceous calcareous nannofossil biostratigraphy. Koninklijk Nederlands Akademie van Wetenschappen. Series B 80. 3: 169-181.

Mutterliose, J. 1989. Temperature-controlled migration of calcareous nannofloras in the north-west European Aptian. In Crux, J. A. \& Heck. S. E. van (Eds), Nannofossils and their Applications, 122-142. Ellis Horwood Ltd., Chichester, for British Micropalaeontological Society.

Mutterlïse, J. 1991. DasVerteilungs - und Migrationsmuster des kalkigen Nannoplanktons in der borealen underkreide (ValanginApt) NW-Deutschland. Palaeontographica. B221: 27-152.

Owen, H. G. 1972. The Gault and its junction with the Woburn Sands in the Leighton Buzzard area, Bedfordshire and Buckinghamshire. Proceedings of the Geologists' Association, 83: $287-312$.

Owen, H. G. 1975. The Stratigraphy of the Gault and Upper Greensand of the Weald. Proceedings of the Geologists Association, 86: 475-498.

Perch-Nielsen, K. 1979. Calcareous nannofossils from the Cretaceous between the North Sea and the Mediterranean. In
Wiedmann, J. (Ed.), Aspekte der Kriede Europas. International Union of Geological Sciences Series A, 6: 223-272.

Perch-Nielsen, K. 1983. Recognition of Cretaceous stage boundaries by means of calcareous nannofossils. In Birkelund, T. et al. (Eds), Symposium on Cretaceous Stage Boundaries, Copenhagen, Abstracts, $152-156$

Perch-Nielsen, K. 1984. Validation of new combinations. International Nannoplankton Association Newsletter, 6(1): 42-46.

Perch-Nielsen, K. 1985. Mesozoic calcareous nannofossils. In Bolli, H. M., Saunders, J. B. \& Perch-Nielsen, K. (Eds), Plankton Stratigraphy, 329-426, Cambridge University Press.

Perch-Nielsen, K. 1988. New Lower Cretaceous calcareous nannofossil species from England. International Nannoplankton Association Newsletter, 10: $30-37$.

Price, F. G. H. 1874. On the Gault of Folkestone. Quarterly Journal of the Geological Society of London, 30: 342-366, pl. 25.

Price, F. G. H. 1879. A Monograph of the Gault. London, i-viii, 1-81. Another edition, 1880

Roth, P. H. 1970. Oligocene calcareous nannoplankton biostratigraphy. Eclogae geologicae Helvetiae, 63: 799-881.

Roth, P. H. 1973. Calcareous nannofossils - Leg 17, DSDP. Initial reports of the Deep Sea Drilling Project, 17: 695-793.

Roth, P. H. 1978. Cretaceous nannoplankton and oceanography of the Northwestern Atlantic Ocean. Initial reports of the Deep Sea Drilling Project, 44: 731-759.

Roth, P. H. \& Thierstein, H.R. 1972. Calcareous nannoplankton: Leg 14 of the DSDP. Initial reports of the Deep Sea Drilling Project, 14: 421-485.

Sissingh, W. 1977. Biostratigraphy of Cretaceous calcareous nannoplankton. Geologie en mijnbouw, 56(1): 37-65.

Spath, L. F. 1924. On the ammonites of the Speeton Clay and the subdivisions of the Neocomian. Geological Magazine, 61: 73-89.

Stover, L. E. 1966. Cretaceous coccoliths and associated nannofossils from France and the Netherlands. Micropalaeontology, 12: 133-167.

Stradner, H. 1961. Vorkommen von Nannofossilien im Mesozoikum und Alttertiär. Erdol Erdgas Kohle, 77: 77-88.

Stradner, H. \& Adamiker, D. 1966. Nannofossilien aus Bohrkernen und ihre elektronenmikroskopische Bearbeitung. Erdol Erdgas Kohle, 82: 330-341.

Stradner, H., Adamiker, D. \& Maresch, O. 1968. Electron microscope studies on Albian calcareous nannoplankton from the Delft 2 and Leidschendam 1 Deep Wells, Holland. Verhandelingen-Koninklijke Nederlandse Akademie van Wetenschappen Afdeling Natuurkunde Tweede Reeks, 24: 1-107.

Taylor, R. J. 1982. Lower Cretaceous (Ryazanian to Albian) calcareous nannofossils. In Lord, A. R. (Ed.), A Stratigraphical Index of Calcareous Nannofossils, 40-80. Ellis Horwood, Chichester, for British Micropalaeontology Society.

Thierstein, H. R. 1971. Tentative Lower Cretaceous calcareous nannoplankton zonation. Eclogae geologicae Helvetiae, 64: 459-488.

Thierstein, H. R. 1973. Lower Cretaceous calcareous nannoplankton biostratigraphy. Abhandlungen der Geologischen Bundesanstalt (Wien), 29: 1-52.

Thierstein, H. R. 1976. Mesozoic calcareous nannoplankton biostratigraphy of marine sediments. Marine Micropaleontology, 1: $325-362$.

Varol, O. 1991. New Cretaceous and Tertiary calcareous Nannofossils. Neues Jahrbuch fur Geologie und Paläontologie. Abhandlungen, 182: 211-237.

Varol, O. 1992. Taxonomic revision of the Polycyclolithaceae and its contribution to Cretaceous biostratigraphy. Newsletters on Stratigraphy, 27(3): 93-127.

Varol, O. \& Girgis, M. H. 1994. New taxa and taxonomy of some Jurassic to Cretaceous calcareous nannofossils. Neues Jahrbuch fur Geologie und Paläontologie. Abhandlungen, 192(2): 221-253.

Varol, O. \& Jakubowski, M. 1989. Some new nannofossil taxa. International Nannoplankton Newsletter, 11(1): 24-29.

Verbeek, J. W. 1977. Calcareous nannoplankton biostratigraphy of middle and Upper Cretaceous deposits in Tunisia, southern 
Spain and France. Utrecht Micropaleontological Bulletins, 16: $1-157$.

Whitham, F. 1991. The stratigraphy of the Upper Cretaceous Ferriby, Welton and Burnham Formations north of the Humber, north-east England. Proceedings of the Yorkshire Geological Society, 48(3): 227-254.

Wise, S. W., Jr. 1983. Mesozoic and Cenozoic calcareous nannofossils recovered by Deep Sea Drilling Project Leg 71 in the Falkland Plateau Region, Southwest Atlantic Ocean. Initial reports of the Deep Sea Drilling Project, 71: 481-550.

Worsley, T. R. 1971. Calcareous nannofossil zonation of Jurassic and Lower Cretaceous sediments from the Western Atlantic. In Farinacci, A. (Ed.), Proceedings II Planktonic Conference Roma, 1970, 1301-1322. Edizioni Tecnoscienza.

Wright, C. W. 1935. In Swinnerton, H. H. A Monograph of British Cretaceous Belemnites. Palaeontographical Society, 1954, Part V, xxxiv-xxxv.

\section{APPENDIX 1: Alphabetical list of species considered in this study}

Acaenolithus cenomanicus Black, 1973

Acaenolithus galloisii Black, 1973

Acaenolithus viriosus n. sp.

Axopodorhabdus albianus (Black, 1967) Wind \& Wise in Wise \& Wind, 1977

Axopodorhabdus dietzmannii (Reinhardt, 1965) Wind \& Wise, 1983

Biscutum constans (Górka, 1957) Black in Black \& Barnes, 1959

Biscutum dissimilis Wind \& Wise in Wise \& Wind, 1977

Bownia glabra n. sp

Braarudosphaera africana Stradner, 1961

Braarudosphaera primula Black, 1973

Braarudosphaera quinquecostata Hill, 1976

Braarudosphaera regularis Black, 1973

Braarudosphaera stenorhetha Hill, 1976

Braloweria boletiformis (Black, 1972) Crux, 1991

Broinsonia enormis (Shumenko, 1968) Manivit, 1971

Bukrylithus ambiguus Black, 1971

Calcicalathina alta Perch-Nielsen, 1979

Calculites anfractus (Jakubowski, 1986) Varol \& Jakubowski, 1989

Calculites dispar Varol in Al-Rifaiy et al., 1990

Calculites percernis n. sp.

Ceratolithina bicornuta Perch-Nielsen, 1988

Ceratolithina cruxii Perch-Nielsen, 1988

Ceratolithina hamata Martini, 1967

Chiastozygus litterarius (Gorka, 1957) Manivit, 1971

Corollithion achlyosum (Stover, 1966) Thierstein, 1971

Corollithion exiguum Stradner, 1961

Corollithion kennedyi Crux, 1981

Corollithion rhombicum (Stradner \& Adamiker, 1966)

Bukry, 1969

Cretarhabdus inaequalis Crux, 1987

Cretarhabdus loriei Gartner, 1968

Crepidolithus burwellensis Black, 1972

Cribrosphaerella ehrenbergii (Arkhangelsky, 1912) Deflandre in Piveteau, 1952

Crucibiscutum hayi (Black, 1971) Jakubowski, 1986

Crucibiscutum salebrosum (Black, 1971) Jakubowski, 1986

Crucibiscutum sp.1 n. sp.
Crucicribrum anglicum Black, 1973

Cyclagelosphaera rotaclypeata Bukry, 1969

Cyclagelosphaera shenleyensis Black, 1973

Discorhabdus ignotus (Gorka, 1957) Perch-Nielsen, 1968

Eiffellithus monechiae Crux, 1991

Eiffellithus turriseiffelii (Deflandre in Deflandre \& Fert, 1954) Reinhardt, 1965

Ellipsagelosphaera britannica (Stradner, 1963) Perch-

Nielsen, 1968

Eprolithus floralis (Stradner, 1962) Stover, 1966

Eprolithus varolii Jakubowski, 1986

Farhania sp. Varol, 1992

Flabellites biforaminis Thierstein, 1973

Gaarderella granulifera Black, 1973

Gartnerago chiasta Varol, 1991

Gartnerago nanum Thierstein, 1974

Gartnerago praeobliquum Jakubowski, 1986

Gartnerago theta (Black, 1959), Jakubowski, 1986

Glaukolithus diplogrammus (Deflandre in Deflandre \& Fert, 1954) Reinhardt, 1964

Goniolithus fluckigeri Deflandre, 1957

Gorkaea operio Varol \& Girgis, 1994

Grantarhabdus coronadventis (Reinhardt, 1966) Grün in Grün \& Allemann, 1975

Haqius circumradiatus (Stover, 1966) Roth, 1978

Hayesites albiensis Manivit, 1971

Helicolithus cf. compactus (Bukry, 1969) Varol \& Girgis, 1994

Hemipodorhabdus gorkae (Reinhardt, 1969) Grün in Grün \& Allemann, 1975

Laguncula dorotheae Black, 1971

Lithraphidites carniolensis Deflandre, 1963

Lordia xenota (Stover, 1966) Varol \& Girgis, 1994

Manivitella pecten Black, 1973

Manivitella pemmatoidea (Deflandre in Manivit, 1965) Thierstein, 1971

Micrantholithus hoschulzii (Reinhardt, 1966) Thierstein, 1971

Microstaurus chiastius (Worsley, 1971) Grün in Grün \& Allemann, 1975

Nannoconus aquitanicus Deres \& Achéritéguy, 1980

Nannoconus elongatus Brönnimann, 1955

Nannoconus grandis Deres \& Achéritéguy, 1980

Nannoconus multicadus Deflandre \& Deflandre, 1959

Nannoconus truitti Brönnimann, 1955

Octocyclus magnus Black, 1972

Orastrum perspicuum Varol in Al-Rifaiy et al., 1990

Owenia hilli Crux, 1991

Parhabdolithus embergeri (Noël, 1965) Stradner, 1963

Percivalia fenestrata (Worsley, 1971) Wise, 1983

Pervilithus varius Crux, 1981

Prediscosphaera columnata (Stover, 1966) Perch-Nielsen, 1984

Prediscosphaera spinosa (Bramlette \& Martini, 1964) Gartner, 1968

Prediscosphaera cf. stoveri Barrier, 1977

Radiolithus hollandicus Varol, 1992

Repagulum parvidentatum (Deflandre in Deflandre \& Fert, 1954) Forchheimer, 1972 
Rhagodiscus achlyostaurion (Hill, 1976) Doeven, 1983 Rhagodiscus angustus (Stradner, 1963) Reinhardt, 1971 Rhagodiscus asper (Stradner, 1963) Reinhardt, 1967 Rhagodiscus infinitus (Worsley, 1971) Applegate et. al. in Covington \& Wise, 1987

Rhagodiscus splendens (Deflandre, 1953) Verbeek, 1977

Rhombolithion rhombicum (Stradner \& Adamiker, 1966) Black, 1973

Rotelapillus crenulatus (Stover, 1966) Perch-Nielsen, 1984 Rothia striata (Black, 1971) Varol \& Girgis, 1994

Scampanella spp. Forchheimer \& Stradner, 1973

Scapholithus fossilis Deflandre in Deflandre \& Fert, 1954

Seribiscutum primitivum (Thierstein, 1974) Filewicz et al, in Wise \& Wind, 1977

Sollasites horticus (Stradner et al. in Stradner \& Adamiker, 1966)

Sollasites lowei (Bukry, 1969) Roth, 1970

Staurolithites angustus (Stover, 1966) Crux, 1991

Staurolithites canthus n. sp.

Staurolithites gausorhethium (Hill, 1966) Varol \& Girgis, 1994

Staurolithites rotatus n. sp.

Stradnerlithus fractus (Black, 1973) Perch-Nielsen, 1984

Tegulalithus tessellatus (Stradner in Stradner et al., 1968) Crux, 1986

Tetrapodorhabdus decorus (Deflandre in Deflandre \& Fert, 1954) Wind \& Wise in Wise \& Wind, 1977

Tranolithus gabalus Stover, 1966

Tranolithus phacelosus Stover, 1966

Watznaueria barnesae (Black in Black \& Barnes, 1959)

Perch-Nielsen, 1968

Zeugrhabdotus sisyphus (Gartner, 1968) Crux, 1989

Zeugrhabdotus noeliae Rood et al., 1971
APPENDIX 2: Stratigraphic details of samples collected at Munday's Hill

\begin{tabular}{lccc}
\hline Stage & $\begin{array}{c}\text { MF Subzone } \\
\text { (Owen, 1972) }\end{array}$ & $\begin{array}{c}\text { No. of } \\
\text { samples } \\
\text { viewed }\end{array}$ & NF Zone \\
\hline Upper Albian & *auritus & 4 & NAL 10 \\
& & 4 & NAL 9 \\
& varicosum & 1 & NAL 8 \\
& orbignyi & 1 & NAL 7 \\
cristatum & 1 & NAL 7 \\
Middle Albian & niobe & 1 & NAL 4 \\
& intermedius & 7 & NAL 4 \\
& spathi & 1 & NAL 4 \\
\hline
\end{tabular}

The nannofossil asssemblages from this locality are discussed by Crux, 1991.

Crux notes both Ceratolithina hamata and Axopodorhabdus albianus together with the absence of Braloweria boletiformis from the niobe MF Subzone (samples 21 and 22). This is in conflict with my results which indicate the FAD of $C$. hamata and consistent $A$. albianus within the cristatum MF Subzone at Munday's Hill. Braloweria boletiformis is present within the niobe $\mathrm{MF}$ Subzone at this locality.

* auritus MF Subzonal assignment (H. G. Owen, pers. comm., 1994)

Manuscript received May 1993 